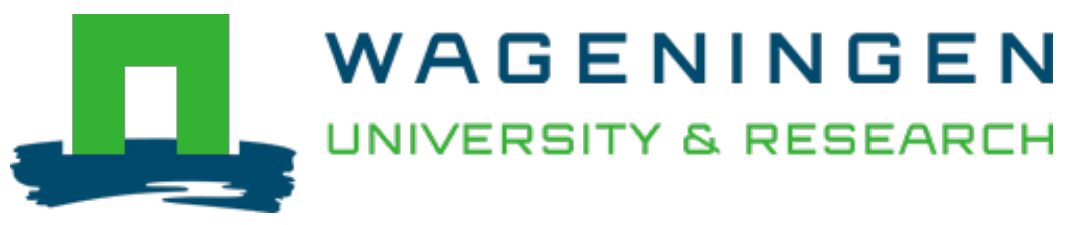

\title{
Salt stress and fluctuating light have separate effects on photosynthetic acclimation, but interactively affect biomass
}

Plant, Cell \& Environment

Zhang, Yuqi; Kaiser, Elias; Marcelis, Leo F.M.; Yang, Qichang; Li, Tao

https://doi.org/10.1111/pce. 13810

This publication is made publicly available in the institutional repository of Wageningen University and Research, under the terms of article $25 \mathrm{fa}$ of the Dutch Copyright Act, also known as the Amendment Taverne. This has been done with explicit consent by the author.

Article 25 fa states that the author of a short scientific work funded either wholly or partially by Dutch public funds is entitled to make that work publicly available for no consideration following a reasonable period of time after the work was first published, provided that clear reference is made to the source of the first publication of the work.

This publication is distributed under The Association of Universities in the Netherlands (VSNU) 'Article $25 \mathrm{fa}$ implementation' project. In this project research outputs of researchers employed by Dutch Universities that comply with the legal requirements of Article $25 \mathrm{fa}$ of the Dutch Copyright Act are distributed online and free of cost or other barriers in institutional repositories. Research outputs are distributed six months after their first online publication in the original published version and with proper attribution to the source of the original publication.

You are permitted to download and use the publication for personal purposes. All rights remain with the author(s) and / or copyright owner(s) of this work. Any use of the publication or parts of it other than authorised under article $25 \mathrm{fa}$ of the Dutch Copyright act is prohibited. Wageningen University \& Research and the author(s) of this publication shall not be held responsible or liable for any damages resulting from your (re)use of this publication.

For questions regarding the public availability of this publication please contact openscience.library@wur.nl 


\title{
Salt stress and fluctuating light have separate effects on photosynthetic acclimation, but interactively affect biomass
}

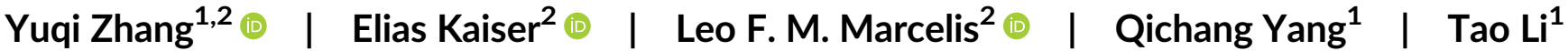

\author{
${ }^{1}$ Institute of Environment and Sustainable \\ Development in Agriculture, Chinese Academy \\ of Agriculture Sciences, Beijing, China \\ ${ }^{2}$ Horticulture and Product Physiology, \\ Department of Plant Sciences, Wageningen \\ University, Wageningen, the Netherlands \\ Correspondence \\ Tao Li, Institute of Environment and \\ Sustainable Development in Agriculture, \\ Chinese Academy of Agriculture Sciences, \\ Beijing, China. \\ Email: litao06@caas.cn \\ Qichang Yang, Institute of Environment and \\ Sustainable Development in Agriculture, \\ Chinese Academy of Agriculture Sciences, \\ Beijing, China. \\ Email: yangqichang@caas.cn \\ Funding information \\ Central Public-interest Scientific Institution \\ Basal Research Fund for Chinese Academy of \\ Tropical Agricultural Sciences, Grant/Award \\ Number: No. BSRF201911; National Key \\ Research and Development Program of China, \\ Grant/Award Number: 2017YFB0403902; \\ National Natural Science Foundation of China, \\ Grant/Award Numbers: No. 31501808, No. \\ 31872955; the 4TU programme \\ "PLANTENNA: Botanic sensor networks, \\ towards an Internet Of Plants"
}

\begin{abstract}
In nature, soil salinity and fluctuating light (FL) often occur concomitantly. However, it is unknown whether salt stress interacts with FL on leaf photosynthesis, architecture, biochemistry, pigmentation, mineral concentrations, as well as whole-plant biomass. To elucidate this, tomato (Solanum lycopersicum) seedlings were grown under constant light (C, $\left.200 \mu \mathrm{mol} \mathrm{m}{ }^{-2} \mathrm{~s}^{-1}\right)$ or $\mathrm{FL}\left(5-650 \mu \mathrm{mol} \mathrm{m} \mathrm{m}^{-2} \mathrm{~s}^{-1}\right)$, in combination with no $(0 \mathrm{mM} \mathrm{NaCl})$ or moderate $(80 \mathrm{mM} \mathrm{NaCl})$ salinity, for 14 days, at identical photoperiods and daily light integrals. FL and salt stress had separate effects on leaf anatomy, biochemistry and photosynthetic capacity: FL reduced leaf thickness as well as nitrogen, chlorophyll and carotenoid contents per unit leaf area, but rarely affected steady-state and dynamic photosynthetic properties along with abundance of key proteins in the electron transport chain. Salt stress, meanwhile, mainly disorganized chloroplast grana stacking, reduced stomatal density, size and aperture as well as photosynthetic capacity. Plant biomass was affected interactively by light regime and salt stress: FL reduced biomass in salt stressed plants by $17 \%$, but it did not affect biomass of non-stressed plants. Our results stress the importance of considering FL when inferring effects of salt-stress on photosynthesis and productivity under fluctuating light intensities.
\end{abstract}

\section{KEYWORDS}

fluctuating light, light acclimation, photosynthesis, salt stress, stomatal conductance, tomato

\section{INTRODUCTION}

In nature, plants usually grow in a dynamic environment, in which light is one of the most prominent factors (Chen, Stutzel, \& Kahlen, 2018; Niinemets \& Valladares, 2004). Light intensity can change over time scales ranging from milliseconds to hours; these changes are caused by, for example, variation of the solar angle, cloud movement, windinduced leaf fluttering and shading from overlapping leaves and neighbouring plants (Pearcy, 1990; Way \& Pearcy, 2012). Besides, plants often experience suboptimal conditions, such as abiotic stresses, concomitantly with light fluctuations. Salt stress, induced by soil salinity, is a growing challenge for agriculture worldwide-approximately $20 \%$ of all irrigated agricultural area is affected by soil salinity and this problem continues to worsen. In the interest of reproducibility, many studies on salt stress are conducted with plants grown under constant diurnal light intensity (Wu, Shu, Wang, Yuan, \& Guo, 2019; Yang, Lv, Li, Lin, \& Xi, 2018). However, plants may perform differently when grown under constant conditions compared with those grown under ever-changing conditions, including fluctuating light (FL; Poorter et al., 2016). To understand how salt-stressed plants perform in the field, it is important to understand how salt-stressed plants respond to light intensity variations.

To quantify the effects of FL on plants, an experimental light source with full control of intensity, timing and frequency is required. Also, fully evaluating the effects of a dynamic light regime requires a control in which irradiance is constant throughout the photoperiod, and whose average intensity and spectrum are the same as that of the treatment(s) containing FL. Such experiments are only possible under 
controlled growth conditions without the interference of sunlight (i.e., not in the field or greenhouse) (Kubásek, Urban, \& Santrucek, 2013; Leakey, Press, Scholes, \& Watling, 2002; VialetChabrand, Matthews, Simkin, Raines, \& Lawson, 2017). Most studies examining acclimation to FL use a simple light pattern focused on frequent, repeated fluctuations between one high and one low intensity (denoted as lightflecks) (Alter, Dreissen, Luo, \& Matsubara, 2012; E. Kaiser, Matsubara, Harbinson, Heuvelink, \& Marcelis, 2018; Schneider et al., 2019). While this approach is powerful for studies on the mechanisms of FL acclimation, it has some drawbacks: On the one hand, it usually incorporates a peak of high light intensity, which is close to or even exceeds the light saturation point of photosynthesis, and thus exposes plants to photooxidative stress; in such cases it is difficult to ascribe the acclimation to FL either due to the fact that light intensity was highly dynamic, or due to repeated photooxidative stress events. On the other hand, such a static FL pattern of repeated lightflecks does not account for the diurnal variation of irradiance, which is often approximated using a sinusoidal pattern with a maximum in the middle of the photoperiod.

Growth under FL involves acclimatory adjustments of leaf morphology (e.g., leaf area, leaf thickness, cell number, cell size and cell arrangement), which are precluded by changes in gene transcription (Schneider et al., 2019) and protein abundance (Caliandro et al., 2013; Vialet-Chabrand et al., 2017). This acclimation affects photosynthesis (including light harvesting, electron transport, $\mathrm{CO}_{2}$ diffusion and carboxylation and dark respiration) and plant growth (Murchie et al., 2018). The most extensive work on acclimation to FL was recently performed by Lawson and co-workers, who found that Arabidopsis thaliana (Arabidopsis), acclimated to FL, showed reductions in leaf thickness, growth rate, photosynthetic capacity and concentrations of proteins in the photosynthetic electron transport chain (Vialet-Chabrand et al., 2017), as well as changes in (diurnal) stomatal kinetics (Matthews, Vialet-Chabrand, \& Lawson, 2018). However, it is unclear how general these effects on photosynthetic acclimation to diurnal FL are for species other than Arabidopsis, for example, crop plants. Further, it is unclear whether salt-stressed plants show similar acclimation as unstressed plants.

Salt stress usually reduces biomass, root: shoot ratio and stomatal conductance $\left(g_{s}\right)$, while increasing leaf thickness (Chaves, Costa, \& Saibo, 2011; Munns \& Tester, 2008). As these traits could also be affected by FL, one may hypothesize that salt stress and FL interact to affect leaf photosynthetic acclimation and plant growth. For example, a reduction in $g_{s}$ is a typical early response to salt stress (Munns \& Tester, 2008), which in $\mathrm{C}_{3}$ leaves can impair leaf $\mathrm{CO}_{2}$ diffusion and thereby decrease photosynthesis (Chaves et al., 2011). Given that $g_{s}$ is a major limitation of photosynthesis in fluctuating irradiance (E. Kaiser et al., 2016; Pearcy, Krall, \& Sassenrath, 1996), especially for salt stressed leaves (Zhang, Kaiser, Zhang, Yang, \& Li, 2018), it can be hypothesized that diurnal photosynthesis and, subsequently, growth of salt-stressed plants is reduced more strongly by $\mathrm{FL}$ compared to constant light intensity.

The aim of this study is to investigate whether and how salt stress interacts with FL on leaf photosynthetic traits and plant growth. With this knowledge it may then be possible to reconsider experimental growth conditions to draw conclusions on how salt-stressed plants may perform under fluctuating light intensity. Tomato (Solanum lycopersicum) was used in this study, as it is a C3 model species with intermediate leaf photosynthetic capacity (E. Kaiser, Kromdijk, Harbinson, Heuvelink, \& Marcelis, 2017), an important crop, and a major vegetable produced over the world (Shahbandeh, 2020). To address the above question, tomato plants, were grown under constant or fluctuating light and were supplied with 0 or $80 \mathrm{mM} \mathrm{NaCl}$. The light fluctuations were on top of sinusoidal pattern (with a maximum in the middle of the photoperiod and minimum at start and end of photoperiod), while avoiding stressful high light intensity. Acclimation and growth traits on chloroplast, leaf and whole plant levels were investigated.

\section{2 | MATERIALS AND METHODS}

\subsection{Plant material and experimental setup}

Tomato seedlings (Solanum lycopersicum cv. Moneymaker) were grown in pots (1.3 L, 135 and $95 \mathrm{~mm}$ in top and bottom diameter, and $125 \mathrm{~mm}$ in height) containing quartz sand in a growth chamber at an ambient $\mathrm{CO}_{2}$ partial pressure, day/night temperature of $22 / 20^{\circ} \mathrm{C}$ and average relative humidity of $65 \%$, according to E. Kaiser et al. (2017). Twenty days after sowing, plants were randomly divided into four groups, which were allocated to the four treatments for 14 days. All treatments were arranged in a growth cabinet that was divided into two layers for two light regimes (Figure 1), and within each light regime, plants were divided into two groups which were allocated to the two $\mathrm{NaCl}$ treatments; this was a split-plot design with light treatment at the whole-plot level and salt stress at the sub-plot level. Treatments were denoted as: (a) CO: constant irradiance and $0 \mathrm{mM}$ $\mathrm{NaCl}$, (b) FLO: fluctuating irradiance and $0 \mathrm{mM} \mathrm{NaCl}$, (c) C80: constant

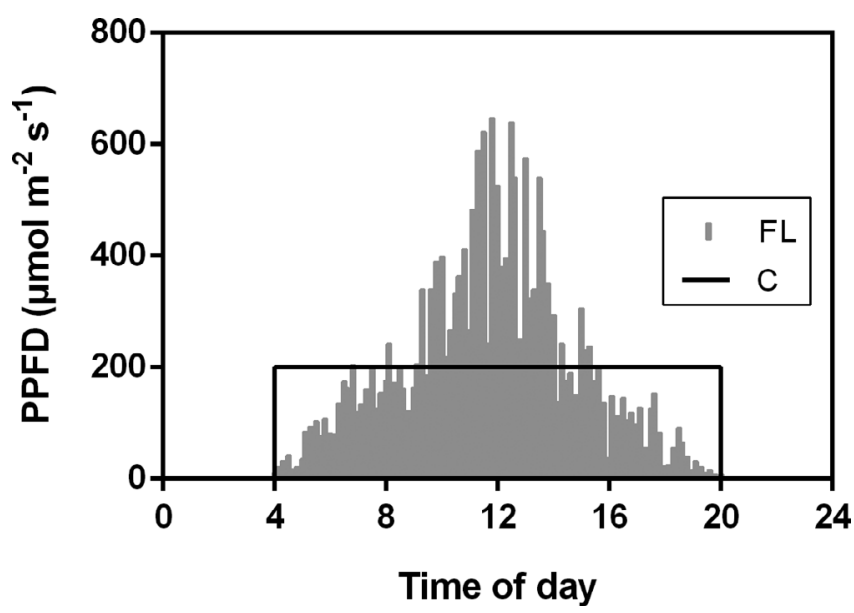

FIGURE 1 Diurnal irradiance patterns used during the 14-day treatment period. C, Constant irradiance $\left(200 \mu \mathrm{mol} \mathrm{m} \mathrm{m}^{-2} \mathrm{~s}^{-1}\right)$; FL, Fluctuating irradiance $\left(5-650 \mu \mathrm{mol} \mathrm{m} \mathrm{m}^{-2} \mathrm{~s}^{-1}\right.$, changing every $\left.5 \mathrm{~min}\right)$. PPFD, Photosynthetic photon flux density 
irradiance and $80 \mathrm{mM} \mathrm{NaCl}$ and (d) FL80: fluctuating irradiance and $80 \mathrm{mM} \mathrm{NaCl}$. Plants in non-stress treatments $(0 \mathrm{mM} \mathrm{NaCl})$ were irrigated with nutrient solution for tomato $(\mathrm{EC} \approx 2.1 \mathrm{dS} / \mathrm{m}, \mathrm{pH} \approx 5.5$ ) (E. Kaiser et al., 2017). For salt-stress treatments, $80 \mathrm{mM}$ of $\mathrm{NaCl}$ was added to the nutrient solution ( $E C \approx 10.0 \mathrm{dS} / \mathrm{m}, \mathrm{pH} \approx 5.5$ ). This concentration $(80 \mathrm{mM})$ is in the range of commonly used concentrations to induce salt stress to tomato plants (Debouba, Gouia, Suzuki, \& Ghorbel, 2006; Mulholland, Taylor, Jackson, \& Thompson, 2003). Plants were irrigated daily, allowing abundant leaching of excess nutrient solution to maintain a stable salt content in the root zone.

Light was provided by white LED light panels and the spectrum was identical between treatments (Figure S1). Light intensity was controlled using a programmable controller. The photoperiod (16 hr) and daily integral (11.5 mol m $\mathrm{m}^{-2} \mathrm{~d}^{-1}$ ) of photosynthetic photon flux density (PPFD) were equal between constant irradiance (C, $200 \mu \mathrm{mol} \mathrm{m}^{-2} \mathrm{~s}^{-1}$ ) and fluctuating irradiance ( $\mathrm{FL}$, following a sinusoidal pattern during the day and on top of that changing every $5 \mathrm{~min}$ in the range of $5-650 \mu \mathrm{mol} \mathrm{m} \mathrm{m}^{-2} \mathrm{~s}^{-1}$; Figure 1). Fluctuations were chosen to be substantial, but not stressful: maximum light intensity was $650 \mu \mathrm{mol} \mathrm{m} \mathrm{m}^{-2} \mathrm{~s}^{-1}$, which is typically far from the light saturation point of photosynthesis in tomato leaves (Lanoue et al., 2019; Zhang, Kaiser, Zhang, Yang, \& Li, 2019). The FL pattern was repeated daily. Plants did not shade each other and the uppermost leaves were kept at the same distance from the light source throughout the whole experiment. To avoid position effects on plant growth, the light regime and the plants belonging to it were interchanged daily between the two layers, and plants within each light regime were rotated randomly. The experiment was repeated five times in succession, with 3-4 plants per treatment and experiment. Except for leaf cross sections and photosynthetic protein analysis (which were analysed in one experiment only), the following measurements were repeated in two to five independent experiments (i.e., 2-5 blocks).

\section{2 | Gas exchange and chlorophyll fluorescence}

Photosynthetic gas exchange and chlorophyll fluorescence measurements were performed on the youngest fully expanded leaf using the LI-6400XT photosynthesis system (Li-Cor Biosciences, Lincoln, NE) equipped with the leaf chamber fluorometer (Li-Cor Part No.6400-40, enclosed leaf area: $2 \mathrm{~cm}^{2}$ ). Unless stated otherwise, all measurements were performed at a leaf temperature of approximately $22^{\circ} \mathrm{C}$, leaf-toair vapour pressure deficit of $0.7-1.0 \mathrm{kPa}$, and flow rate of air through the system of $500 \mu \mathrm{mol} / \mathrm{s}$. Irradiance was provided by a mixture of red (90\%) and blue (10\%) LEDs in the fluorometer. Peak intensities of red and blue LEDs were at wavelengths of 635 and $465 \mathrm{~nm}$, respectively.

\subsection{1 | Light and $\mathrm{CO}_{2}$ response curves of leaf photosynthesis}

Light response curves of leaf photosynthesis were performed under non-photorespiratory and photorespiratory conditions (2 and 21\% oxygen, respectively). Leaves were adapted to $200 \mu \mathrm{mol} \mathrm{m}{ }^{-2} \mathrm{~s}^{-1}$
PPFD, $1500 \mu$ bar $\mathrm{CO}_{2}$ and $2 \% \mathrm{O}_{2}$, until leaf net photosynthesis rate (A) was stable. Leaves were then exposed to a range of PPFDs $\left(200,150,100,50,0 \mu \mathrm{mol} \mathrm{m}{ }^{-2} \mathrm{~s}^{-1}\right)$. Then, $\mathrm{CO}_{2}$ partial pressure was decreased to $400 \mu$ bar $\mathrm{CO}_{2}$ and $\mathrm{O}_{2}$ was increased to $21 \%$. After leaves were dark-adapted in the Li-6400 XT leaf chamber for approximately $30 \mathrm{~min}$, gas exchange parameters together with minimal $\left(F_{0}\right)$ and maximal $\left(F_{\mathrm{m}}\right)$ chlorophyll fluorescence were recorded to determine the maximum quantum efficiency of photosystem II (PSII) photochemistry $\left(F_{v} / F_{m}\right)$. PPFD was then increased in steps of 50, 100, 150, 200, 250, 500, 1,000, 1,500 and $2000 \mu \mathrm{mol} \mathrm{m} \mathrm{m}^{-2} \mathrm{~s}^{-1}$. Upon reaching steady-state conditions at each PPFD (10-15 min), gas exchange parameters were logged continuously (every $5 \mathrm{~s}$ ) for 1 min, and averages of 12 values were used at each PPFD step. At each PPFD, a multiphase flash (MPF) chlorophyll fluorescence routine was executed to determine the fluorescence yield under actinic light $\left(F_{\mathrm{s}}\right)$, as well as maximum $\left(F_{\mathrm{m}}{ }^{\prime}\right)$ and minimum $\left(F_{0}{ }^{\prime}\right)$ fluorescence, following recommended procedures (Loriaux et al., 2013). Settings of the MPF were determined in a preliminary experiment: the measuring beam intensity was $1 \mu \mathrm{mol} \mathrm{m} \mathrm{m}^{-2} \mathrm{~s}^{-1}$, maximum flash intensity was $8,500 \mu \mathrm{mol} \mathrm{m} \mathrm{m}^{-2} \mathrm{~s}^{-1}$, flash intensity decreased by $60 \%$ during the second phase of the MPF and the durations of the three flash phases were $0.3,0.7$ and $0.4 \mathrm{~s}$, respectively.

Response curves of photosynthesis against leaf internal $\mathrm{CO}_{2}$ partial pressure $\left(C_{i} ; A / C_{i}\right)$ were performed in non-photorespiratory and in photorespiratory conditions. Leaves were adapted in the LI-6400XT leaf chamber to $1,500 \mu \mathrm{mol} \mathrm{m} \mathrm{s}^{-1}$ PPFD, $200 \mu \mathrm{bar} \mathrm{CO}_{2}$ and $2 \%$ oxygen, and $\mathrm{CO}_{2}$ partial pressure was changed stepwise $(200,150$, $100,70,50,30 \mu$ bar). Then, $\mathrm{O}_{2}$ was increased to $21 \%$, and $\mathrm{CO}_{2}$ partial pressure was increased in steps of $30,50,70,100,150,200$, $300,400,600,800,1,000,1,200$ and $1,500 \mu$ bar. Upon reaching steady-state conditions at each $\mathrm{CO}_{2}$ point (3-5 min), gas exchange parameters were logged continuously (every $5 \mathrm{~s}$ ) for $1 \mathrm{~min}$, and averages of 12 values were used at each $\mathrm{CO}_{2}$ step.

\subsection{2 | Analysis of steady-state leaf photosynthesis}

Data were corrected for leakage of $\mathrm{CO}_{2}$ into or out of the cuvette, by using photosynthetically inactive leaves (Flexas et al., 2007). A nonrectangular hyperbolic function (Cannell, G, Thornley, \& G, 1998) was fitted to the light response curve measured under photorespiratory conditions, and parameters were derived including maximum net photosynthesis rate $\left(A_{\max }\right)$ and apparent quantum yield $(\alpha)$. Linear electron transport rate $(J)$ through PSII was calculated according to Tomeo and Rosenthal (2018) as $J=4^{*}\left(\Phi_{\mathrm{PSII}}-b\right) / k$, where, $\Phi_{\mathrm{PSII}}=\left(F_{\mathrm{m}}{ }^{\prime}-F_{\mathrm{s}}\right) / F_{\mathrm{m}}{ }^{\prime}$; $k$ and $b$ are the slope and intercept of the linear regression of $\Phi_{\mathrm{PSII}}$ and quantum yield of $\mathrm{CO}_{2}$ fixation $\left(\Phi_{\mathrm{CO} 2}\right)$ under non-photorespiratory conditions, which were 8.88 and 0.045 in all treatments. Maximum electron transport rate $\left(J_{\max }\right)$ was derived according to Sharkey (2016) using calculated $J$ of the $A / Q$ curve under photorespiratory conditions. Mesophyll conductance $\left(g_{\mathrm{m}}\right)$ at $400 \mu$ bar $\mathrm{CO}_{2}$ was calculated using the variable J method (Harley, Loreto, di Marco, \& Sharkey, 1992). 
Maximum carboxylation rate $\left(\mathrm{V}_{\mathrm{cmax}}\right)$ and triose phosphate use (TPU) were derived according to Sharkey, Bernacchi, Farquhar, and Singsaas (2007) on $A / C_{i}$ curves under photorespiratory conditions. Nonphotochemical quenching (NPQ) was calculated as $\mathrm{NPQ}=F_{\mathrm{m}} / F_{\mathrm{m}}{ }^{\prime}-1$.

Photosynthetic parameters were expressed in two ways: areabased and mass-based. All measurements above were at first recorded on an area basis. They were later converted to units per leaf mass by multiplying them with specific leaf area (SLA; leaf area: leaf mass ratio) for the given leaves.

\subsection{3 | Dynamic photosynthetic responses to step changes in irradiance}

To assess the response of gas exchange and chlorophyll fluorescence to a step increase in PPFD, leaves were dark-adapted in the Li-6400 XT leaf chamber for approximately $30 \mathrm{~min}$, and $F_{0}$ and $F_{m}$ were recorded. Then, irradiance was increased to $50 \mu \mathrm{mol} \mathrm{m} \mathrm{m}^{-2} \mathrm{~s}^{-1}$, and leaves were kept at this PPFD until $A$ and $g_{s}$ were stable (approximately $30 \mathrm{~min}$ ). Then, PPFD was increased in a single-step change to $1,500 \mu \mathrm{mol} \mathrm{m}{ }^{-2} \mathrm{~s}^{-1}$ for $30 \mathrm{~min}$, and $A, g_{\mathrm{s}}$ and $C_{\mathrm{i}}$ were logged automatically once per second. $F_{\mathrm{s}}$ and $F_{\mathrm{m}}{ }^{\prime}$ were logged every minute during the first 10 min of induction, and every 2 min thereafter.

To examine the responses of photosynthetic gas exchange to regular changes between high and low irradiance (lightflecks), leaves were adapted to $1,500 \mu \mathrm{mol} \mathrm{m}{ }^{-2} \mathrm{~s}^{-1}$ PPFD until $A$ and $g_{\mathrm{s}}$ were stable (30-40 min). Then, leaves were subjected to four cycles of $2 \mathrm{~min}$ of low $\left(50 \mu \mathrm{mol} \mathrm{m} \mathrm{m}^{-2} \mathrm{~s}^{-1}\right)$ followed by $2 \mathrm{~min}$ of high $\left(1,500 \mu \mathrm{mol} \mathrm{m} \mathrm{m}^{-2} \mathrm{~s}^{-1}\right)$ PPFD, and gas exchange was logged once per second.

\section{3 | Growth analysis}

Destructive measurements (described below) were taken after 14 days of treatment. Leaf area was measured using the Li-3100 leaf area meter (LI-COR Biosciences, Lincoln, NE). Leaves, stems and roots were dried at $80^{\circ} \mathrm{C}$ for 3 days. Total biomass and allometric relationships [specific leaf area (SLA) and shoot: root ratio (S:R)] were calculated.

\subsection{Leaf chemical components and pigments}

\subsubsection{Leaf chemical components}

Dry leaf material from whole plants was pooled for each treatment after every round of experiment, and $3 \mathrm{~g}$ per sample were used to determine leaf $\mathrm{N}, \mathrm{C}, \mathrm{Na}^{+}$and $\mathrm{K}^{+}$contents. $\mathrm{N}$ and $\mathrm{C}$ contents were determined with a $\mathrm{C} / \mathrm{N}$ analyzer (IsoPrime 100; Isoprime Ltd., Manchester, UK). $\mathrm{Na}^{+}$and $\mathrm{K}^{+}$were determined with Shimadzu AA-6800 atomic absorption spectrophotometer (Shimadzu, Tokyo, Japan).

\subsection{2 $\quad$ Leaf pigments}

Leaf discs $\left(1.0 \mathrm{~cm}^{2}\right)$, taken from the youngest fully expanded leaves, were collected and stored in $10 \mathrm{ml} 95 \%$ ethanol in the dark at $4^{\circ} \mathrm{C}$ for $72 \mathrm{hr}$. The absorbance of the extract was measured at 470, 649 and $664 \mathrm{~nm}$ using a UV-Vis spectrophotometer (UV-1800, Shimadzu, Japan). The chlorophyll $a$, chlorophyll $b$ and total carotenoid contents were calculated using the equations derived by Lichtenthaler and Buschmann (Lichtenthaler \& Buschmann, 2001).

\section{5 | Stomatal morphological traits}

Stomatal features were determined using the silicon rubber impression technique (Savvides, Fanourakis, \& van leperen, 2012) on both leaf surfaces of the youngest fully expanded leaves. Epidermal impressions were placed on microscope slides and analyzed using an optical microscope (XSP-13 CC, Caikon, China) equipped with a digital camera (CK-300, Caikon, China). Five fields of view $\left(0.08 \mathrm{~mm}^{2}\right)$ were randomly selected from each sampling area (i.e., five technical replicates), where stomatal and epidermal cell numbers were counted. Stomatal density (SD) was calculated as the number of stomata per unit leaf area and stomatal index (SI) was calculated as ratio of stomatal to epidermal cells. To estimate stomatal and pore area, 20 stomata were randomly selected from each sampled area and stomatal length and width along with pore length and aperture were measured (Savvides et al., 2012). To calculate pore and stomatal area (i.e., including guard cell area), it was assumed that pores and stomata were elliptical (Savvides et al., 2012). Pore area per leaf area was calculated as the average of pore area per stoma $\times$ SD of each leaf surface (Savvides et al., 2012).

\subsection{Leaf optical properties}

Leaf light reflectance and transmittance of the youngest fully expanded leaves were measured with a spectroradiometer (Ocean optics USB2000+, Dunedin, FL) in combination with two integrating spheres (FOIS-1, ISP-REF, Dunedin, FL) and a built-in tungstenhalogen light source. Leaf light absorptance $(A)$ was calculated as: $A=1-(R+T)$, where $R$ and $T$ are the reflectance and transmittance of light by leaf samples.

\subsection{Leaf cross-section microscopy and transmission electron microscopy}

\subsection{1 | Leaf cross-section microscopy}

Leaf segments of $1 \times 1 \mathrm{~cm}$ of the central leaf blade next to the main vein of the youngest fully expanded leaves were cut and fixed for at least $24 \mathrm{hr}$ in a formaldehyde-based fixative (FAA). Then, leaf segments were dehydrated and embedded in paraffin, and sectioned with 
a microtome (RM2016, Leica Microsystems, Shanghai, China). The sections were stained with both safranin and Fast Green and then examined under a microscope (BX53, Olympus Optical Co. Ltd., Tokyo, Japan).

\subsection{2 | Leaf transmission electron microscopy}

Leaf segments $\left(4 \mathrm{~mm}^{2}\right)$ of the central leaf blade next to the main vein of the youngest fully expanded leaves were cut and fixed with $2.5 \%$ glutaraldehyde in $0.2 \mathrm{M}$ sodium phosphate buffer $(\mathrm{pH} 7.2)$ at $4^{\circ} \mathrm{C}$ for $8 \mathrm{hr}$. Thereafter, samples were washed $3 \times$ with phosphate buffer, and incubated with $1 \%$ osmium tetroxide in the same buffer for $2 \mathrm{hr}$. Subsequently, three washes with phosphate buffer were performed. Samples were then dehydrated with an ethanol series (30-100\% ethanol; rest $\mathrm{H}_{2} \mathrm{O}$ ) and propylene oxide, and then embedded in Epon-812 resin. Polymerized blocks were sectioned into $60-80 \mathrm{~nm}$ slices with a ultramicrotome (UC7, Leica Microsystems, Shanghai, China). Then, sections were collected on copper grids and stained with uranyl acetate and thereafter with lead citrate. Finally, the thickness and width of grana stacks were examined under a transmission electron microscope (HT7700, Hitachi Co. Ltd., Tokyo, Japan).

\section{8 $\quad$ Protein extraction and western blotting}

The youngest fully expanded leaves were collected, immediately plunged into liquid nitrogen, and stored at $-80^{\circ} \mathrm{C}$. Samples from three replicate plants were pooled for each treatment. Protein was extracted in extraction buffer $(20 \mathrm{mM}$ Tris- $\mathrm{HCl}, \mathrm{pH} 7.5,100 \mathrm{mM}$ $\mathrm{NaCl}, 2.5 \mathrm{mM} \mathrm{MgCl}$, $1 \mathrm{mM}$ EDTA, $1 \mathrm{mM}$ DTT, $0.5 \mathrm{mM}$ PMSF), and insoluble material was removed by centrifugation at $1,200 \mathrm{rpm}$ for $20 \mathrm{~min}\left(4^{\circ} \mathrm{C}\right)$. Protein was quantified after Bradford (Bradford, 1976). Samples containing $12 \mu \mathrm{g}$ total protein were loaded and then separated using $12 \%(\mathrm{~W} / \mathrm{V})$ SDS-PAGE, transferred to a polyvinylidene difluoride membrane, and probed using antibodies raised against the photosystem II PsbD/D2 and Lhcb2 proteins, the photosystem I Lhca1 protein, and the cytochrome $b_{6} f$ complex protein Cyt $b_{6}$; all antibodies were purchased from Agrisera (Umea, Sweden). Blots were detected using Clarity Western ECL Substrate (Bio-Rad, CA) and visualized by Image Lab (Bio-Rad). Protein content was quantified using ImageJ (https://imagej.nih.gov/ij/) and expressed as a percentage of protein levels in CLO treated plants.

\subsection{Statistical design and analysis}

Statistics were performed using Genstat 19th edition (VSN International, Hempstead, UK). Data were analysed by split-plot design with light pattern (I) as the whole plot, salt stress (S) as the sub-plot, and each independent experiment as a block. If there was an interaction effect on a given trait (i.e., I $\times$ S), least significant differences (LSD) of treatment effects were determined $(p=.05)$, and if not, main effects of I and S were tested. In case of the immunoblot analysis, treatments were compared against CO using a two-tailed one-sample Student's $t$ test.

\section{3 | RESULTS}

\section{1 | Steady-state photosynthesis}

Salt stress affected steady-state photosynthesis regardless of light regime. Maximum steady-state net photosynthesis rate $\left(A_{\max }\right)$ as well as electron transport rate $\left(J_{\max }\right)$ were decreased by $10 \%$ due to salt stress (Figure 2a, b; Table 1). Quantum yield ( $\alpha$ ) and maximum carboxylation rate $\left(V_{c, \text { max }}\right)$ were also decreased $7-10 \%$ by salt stress (Table 1). Mesophyll conductance $\left(g_{m}\right)$ was unaffected by both light regime and salt stress (Table 1 ), while stomatal conductance $\left(g_{s}\right)$ was only significantly affected by salt stress (17-54\% reduction; Figure 2c). When expressing photosynthesis per unit leaf mass rather than per unit leaf area, neither salt stress nor light regime had an effect on traits of steady-state photosynthesis (Table S1). Steadystate responses of $\Phi_{\mathrm{PSII}}$ and NPQ to different PPFD were unaffected by the treatments (Figure S2). Dark-adapted $F_{\mathrm{v}} / F_{\mathrm{m}}$ was approximately 0.83 in all cases without significant treatment effects, suggesting that leaves were not strongly photo-inhibited under any treatment.

\section{2 | Dynamic responses of leaf photosynthesis to changes in irradiance}

After the transition from shade $\left(50 \mu \mathrm{mol} \mathrm{m} \mathrm{m}^{-2} \mathrm{~s}^{-1}\right)$ to high light $\left(1,500 \mu \mathrm{mol} \mathrm{m} \mathrm{m}^{-2} \mathrm{~s}^{-1}\right), \quad A$ gradually increased in all treatments (Figure 3a). At any time during photosynthetic induction, $A$ was $10 \%$ lower in salt-stressed leaves than in non-stressed leaves, while light pattern had no effects (Figure 3a). However, the rate of photosynthetic induction was similar in all treatments (Figure 3a), as shown by similar times to reach $50 \%\left(t_{50}\right)$ and $90 \%\left(t_{90}\right)$ of final photosynthesis rates (Table 1). This lack of a treatment effect on photosynthetic induction rate was surprising, given that initial $g_{s}$ in shade-adapted leaves was significantly lower (33\%) in salt-stressed leaves, compared to non-salt stressed leaves (Figure 3b, Table 1), resulting in a in lower $C_{i}$ (Figure 3c). The $g_{s}$ after induction $\left(g_{s 1500}\right)$ was also $30 \%$ lower in salt-stressed leaves than in non-stressed leaves, while light pattern had no effects (Table 1). All treatments showed similar $\Phi_{\mathrm{PSII}}$ during photosynthetic induction (Figure 3d, Table 1). In all treatments, NPQ reached a plateau within 5 min, but with a $6 \%$ higher value in $\mathrm{FL}$ grown leaves than $C$ grown leaves and with no effect of salt stress (Figure 3e, Table 1). When leaves initially adapted to high light were exposed to a series of lightflecks ( $2 \mathrm{~min}$ of $1,500 \mu \mathrm{mol} \mathrm{m} \mathrm{m}^{-2} \mathrm{~s}^{-1}$, interspersed with $2 \mathrm{~min}$ of $50 \mu \mathrm{mol} \mathrm{m} \mathrm{m}^{-2} \mathrm{~s}^{-1}$ ), average $A$ and $g_{\mathrm{s}}$ were reduced by 12 and $30 \%$ in salt-stressed leaves compared to nonstressed leaves, with no effect of the growth light regime (Figure $3 f-j$ ). 
TAB LE 1 Parameters characterizing steady-state and dynamic photosynthesis

\begin{tabular}{|c|c|c|c|c|c|c|c|c|}
\hline & & \multicolumn{4}{|c|}{ Treatment } & \multicolumn{3}{|c|}{$p$-value } \\
\hline \multirow[t]{5}{*}{ Steady-state } & $A_{\max }\left(\mu \mathrm{mol} \mathrm{m}{ }^{-2} \mathrm{~s}^{-1}\right)$ & 31.2 & 29.3 & 27.7 & 27.1 & .266 & .007 & .319 \\
\hline & $\alpha\left(\mu \mathrm{mol} \mu \mathrm{mol}^{-1}\right)$ & 0.073 & 0.073 & 0.068 & 0.070 & .53 & .030 & .514 \\
\hline & $V_{c \max }\left(\mu \mathrm{mol} \mathrm{m}^{-2} \mathrm{~s}^{-1}\right)$ & 115.1 & 109.8 & 103.4 & 103.3 & .364 & .030 & .394 \\
\hline & $J_{\max }\left(\mu \mathrm{mol} \mathrm{m}{ }^{-2} \mathrm{~s}^{-1}\right)$ & 212.8 & 216.5 & 191.3 & 196.0 & .459 & .014 & .932 \\
\hline & $g_{m}\left(\mathrm{~mol} \mathrm{~m}^{-2} \mathrm{~s}^{-1}\right)$ & 0.34 & 0.28 & 0.29 & 0.33 & .436 & .981 & .280 \\
\hline \multirow[t]{6}{*}{ Photosynthetic induction } & $A_{50}\left(\mu \mathrm{mol} \mathrm{m}{ }^{-2} \mathrm{~s}^{-1}\right)$ & 2.0 & 2.0 & 1.9 & 2.3 & .087 & .582 & .368 \\
\hline & $A_{1500}\left(\mu \mathrm{mol} \mathrm{m}{ }^{-2} \mathrm{~s}^{-1}\right)$ & 24.8 & 25.9 & 22.1 & 21.9 & .376 & .035 & .595 \\
\hline & $t_{50}(\min )$ & 1.7 & 1.4 & 2.2 & 1.9 & .484 & .145 & .860 \\
\hline & $t_{90}(\min )$ & 6.2 & 5.1 & 7.8 & 6.8 & .529 & .120 & .964 \\
\hline & $\Phi_{\mathrm{PSII} 1500}$ & 0.31 & 0.32 & 0.30 & 0.29 & .674 & .195 & .432 \\
\hline & $N P Q_{1500}$ & 1.57 & 1.42 & 1.51 & 1.48 & .031 & .886 & .126 \\
\hline
\end{tabular}

Note: Tomato plants were grown for 14 days under four treatments: CO (constant irradiance $+0 \mathrm{mM} \mathrm{NaCl}$ ), FLO (fluctuating irradiance $+0 \mathrm{mM} \mathrm{NaCl),} \mathrm{C80}$ (constant irradiance $+80 \mathrm{mM} \mathrm{NaCl}$ ) and FL80 (fluctuating irradiance $+80 \mathrm{mM} \mathrm{NaCl}$ ). $A_{\max }$, light-saturated net photosynthesis rate; $R_{\text {dark }}$, dark respiration rate; $\alpha$, quantum yield; $V_{c \max }$, maximum carboxylation rate; TPU; triose phosphate use; $J_{\max }$, maxmum electron transport rate; $g_{\mathrm{m}}$, mesophyll conductance. $A_{50}$ and $A_{1500}$, steady-state net photosynthesis rate at 50 and $1,500 \mu \mathrm{mol} \mathrm{m} \mathrm{m}^{-2} \mathrm{~s}^{-1}$ PPFD, respectively; gs $s_{50}$ steady-state stomatal conductance at $50 \mu \mathrm{mol} \mathrm{m}{ }^{-2} \mathrm{~s}^{-1}$ PPFD; gs ${ }_{1500}$, stomatal conductance after $30 \mathrm{~min}$ of photosynthetic induction. IS ${ }_{60}$, the photosynthetic induction state at $60 \mathrm{~s} ; t_{50}$ and $t_{90}$, the time required to reach $50 \%$ and $90 \%$ of full photosynthetic induction, respectively. $\Phi_{\mathrm{PSII} 1500}$ and $\mathrm{NPQ}_{1500}$, steady-state values (average values during 26-30 min of high light) of $\Phi_{\mathrm{PSII}}$ and NPQ at the end of photosynthetic induction, respectively. Mean values of three independent experiments are shown $(n=3)$, with 2-3 replicate plants per experiment. $p$-values of main effects of light pattern $(I)$ and salt stress $(S)$ and interaction effect $(I \times S)$ are shown, significant effects are printed bold.

\section{3 | Leaf optical properties, pigmentation and chemical composition}

In leaves growing under FL, there was a tendency for leaf light absorption to be slightly reduced in photosynthetically active radiation (PAR, 400-700 nm, $P_{1}=0.099$, Figure S3 and Table S2). This slight reduction in leaf irradiance absorption was caused both by increases in reflection and transmission (Figure S3). Concomitant with the tendency for reduced leaf light absorption, in leaves grown under FL, chlorophyll and carotenoid contents were both $5 \%$ lower compared to $C$ irradiance (Table 2), with no effect of salt stress. Per unit dry mass, however, all effects due to light pattern were nullified, while salt stress significantly (6\%) reduced leaf carotenoid concentration (Table 2). Thus, leaves under all treatments allocated just as much energy to leaf chlorophyll pigmentation.

As expected, leaf $\mathrm{Na}^{+}$content increased strongly in salt-stressed leaves, whereas $\mathrm{K}^{+}$content halved, strongly increasing the $\mathrm{Na}^{+} / \mathrm{K}^{+}$ ratio in salt-stressed leaves (Table 2). Within the same salt treatment, the values of $\mathrm{Na}^{+}$and $\mathrm{K}^{+}$were similar (Table 2). Besides, total contents of $\mathrm{Na}^{+}$and $\mathrm{K}^{+}$were similar between the four treatments (41-$45 \mathrm{mg} \mathrm{g}^{-1} \mathrm{DW}$ ). Salt stress further led to a significant (8\%) reduction in leaf nitrogen content, as well as a slight (3\%) but significant reduction in leaf carbon content (Table 2). FL slightly (5\%) decreased leaf nitrogen content per unit leaf area (Table 2).

\subsection{Leaf anatomy and stomatal traits}

Specific leaf area (SLA) was slightly (7\%) larger under FL than C ( $p=.04$; Figure 4a), indicating a reduced leaf thickness, which was confirmed by measurements on leaf cross sections (Figure $4 b$ ). The change in leaf thickness was predominantly driven by changes in the spongy parenchyma (Figure S4).

Stomatal index and stomatal area on both sides of the leaf were largely (20-40\%) reduced in salt-stressed leaves, whereas the irradiance pattern caused no significant effects (Table 3). Stomatal density was reduced by both salt stress and light regime on the adaxial side of the leaf, with a $20 \%$ reduction in $\mathrm{FL}$ and $50 \%$ reduction in salt stress, but curiously it was unaffected on the abaxial side (Table 3). Salt stress decreased total pore area per leaf area on both sides of the leaf by $60 \%$, but this reduction was only significantly different on the adaxial side (Table 3). 


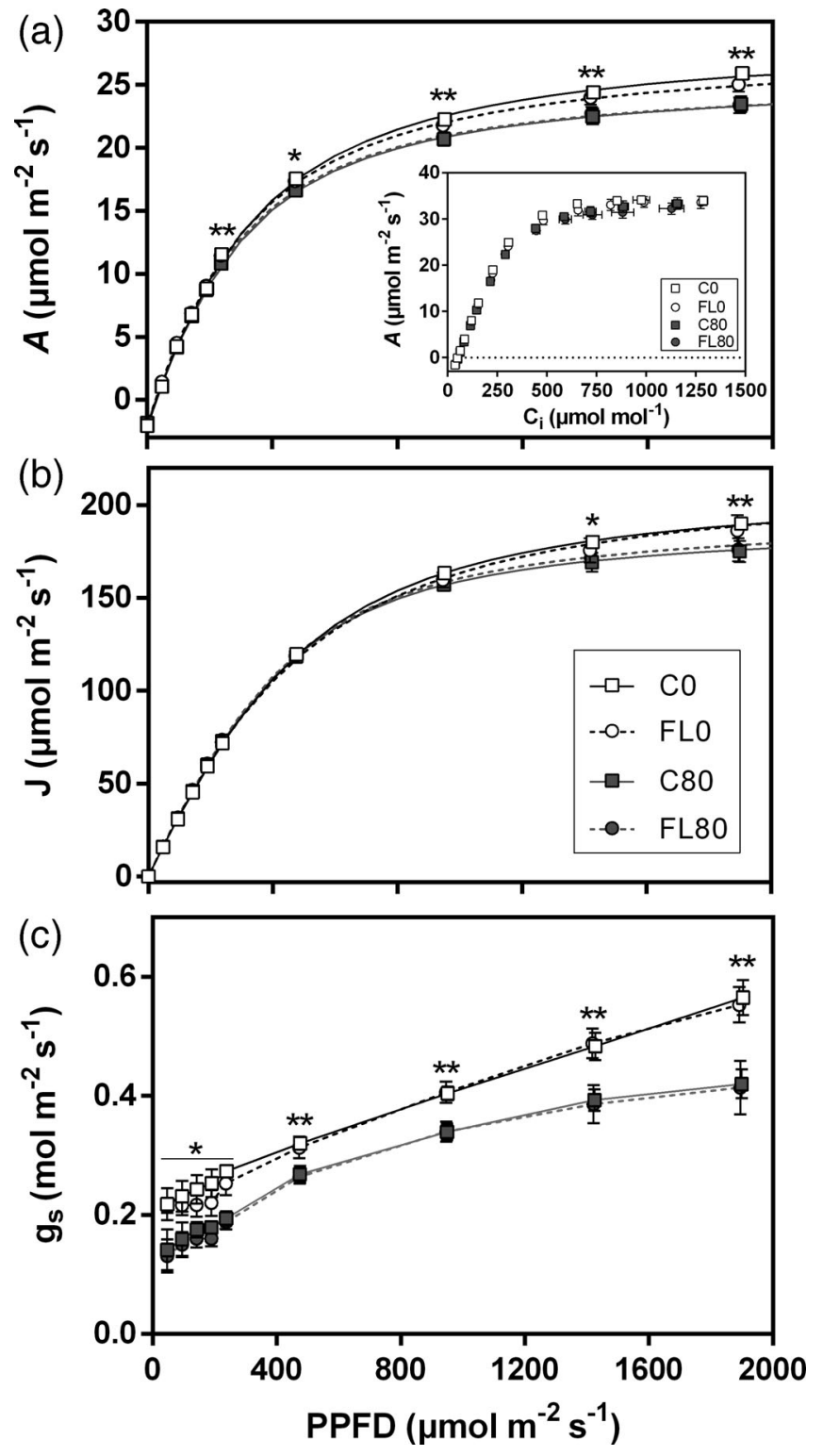

FIGURE 2 Steady-state photosynthesis traits. Responses of leaf net photosynthesis rate $(A ; a)$, linear electron transport rate $(J ; b)$ and stomatal conductance $\left(g_{s} ; c\right)$ to PPFD absorbed by the leaf. The inset in (a) shows responses of $A$ to leaf internal $\mathrm{CO}_{2}$ partial pressure $\left(C_{i}\right)$. Plants were grown for 14 days under four treatments: $\mathrm{CO}$ (constant irradiance $+0 \mathrm{mM} \mathrm{NaCl}$ ), FLO (fluctuating irradiance+0 mM NaCl), C80 (constant irradiance $+80 \mathrm{mM} \mathrm{NaCl}$ ) and $\mathrm{FL} 80$ (fluctuating irradiance $+80 \mathrm{mM}$ $\mathrm{NaCl}$ ). Mean values \pm SEM of three independent experiments are shown $(n=3)$ and SEM can only be observed when larger than data point symbol. Asterisks indicate significant difference between saltstressed (80 mM) and non-stressed ( $0 \mathrm{mM}$ ) group, ${ }^{*} p<.05,{ }^{* *} p<.01$

\section{5 | Chloroplast ultrastructure and photosynthetic protein contents}

Chloroplast ultrastructure and photosynthetic protein contents were measured in one experiment. In the chloroplasts of leaves growing in the absence of salt stress, the grana lamellae were organized in stacks, whereas salt stress reduced grana stacking and dilated the thylakoid lumen (Figure S5). Western blot analysis revealed that relative to $\mathrm{CO}$, leaves of salt-stressed plants growing under constant light showed a approximately $40 \%$ reduction in the photosystem I Lhca1 protein (Figure S6). There were no differences in the concentrations of photosystem II D2 and Lhcb2 proteins, nor for cyt b 6 (Figure S6).

\section{6 | Plant growth}

Salt stress severely reduced plant size (Figure 5a), and this effect interacted with the growth light regime. Under constant light ( $\mathrm{CO}$ and C80), salt stress reduced whole plant dry mass by approximately $33 \%$, while under fluctuating light (FLO and FL80), it had an even stronger impact ( $46 \%$ reduction; Figure $5 \mathrm{~b}$ ). Strikingly, in non-stressed plants ( $\mathrm{CO}$ and $\mathrm{FLO}$ ), FL by itself did not reduce plant biomass compared to $\mathrm{C}$ (Figure 5b), while under salt stress (C80 and FL80) FL significantly decreased plant growth by $17 \%$. Similar patterns as for whole plant biomass were observed for leaf area and whole shoot fresh weight (Table 4), with significant interactions $(p<.05)$ between the two treatment factors in these cases. Salt stress significantly affected almost all evaluated plant growth parameters, except leaf dry matter content and the shoot: root ratio (Table 4). Growth under fluctuating light significantly reduced leaf number, stem diameter (increased specific stem length) and the shoot: root ratio (Table 4).

\section{4 | DISCUSSION}

We have for the first time analysed the effects of fluctuating irradiance in combination with salt stress on growth and photosynthetic physiology. We chose an experimental approach in which fluctuating irradiance was applied such that it followed a sinusoidal pattern during the day with additional short-term fluctuations that were substantial, but hardly stressful. We found that salt stress and fluctuating light affected anatomy, biochemistry and photosynthetic parameters of tomato leaves separately, but affected biomass interactively.

\section{1 | Photosynthetic acclimation to fluctuating light, depending on species and light regime}

Plant morphology and physiology exhibits plasticity in response to light (Hoshino, Yoshida, \& Tsukaya, 2019; Niinemets, 2007). Growing under FL, leaves may show different acclimation traits compared to leaves grown under constant light (C) (Pao, Stutzel, \& Chen, 2019; Vialet-Chabrand et al., 2017). Here, compared to C, acclimation to FL resulted in thinner leaves with lower $\mathrm{N}$ and chlorophyll contents (per unit leaf area), coinciding with a tendency for reduction in leaf irradiance absorption (Figures 4 and Figure S3; Table 2), but maintained similar properties of steady-state and dynamic leaf photosynthesis (Figures 2 and 3; Table 1). To explore whether acclimation to FL is similar across species and light regimes, we compared our results with published data. We selected studies in which a constant irradiance treatment as control and an identical average irradiance between treatments was kept. 
(a) Photosynthetic induction

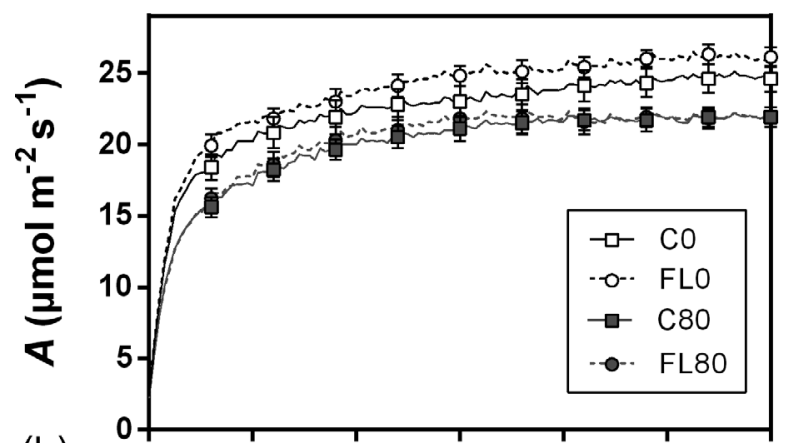

(b)
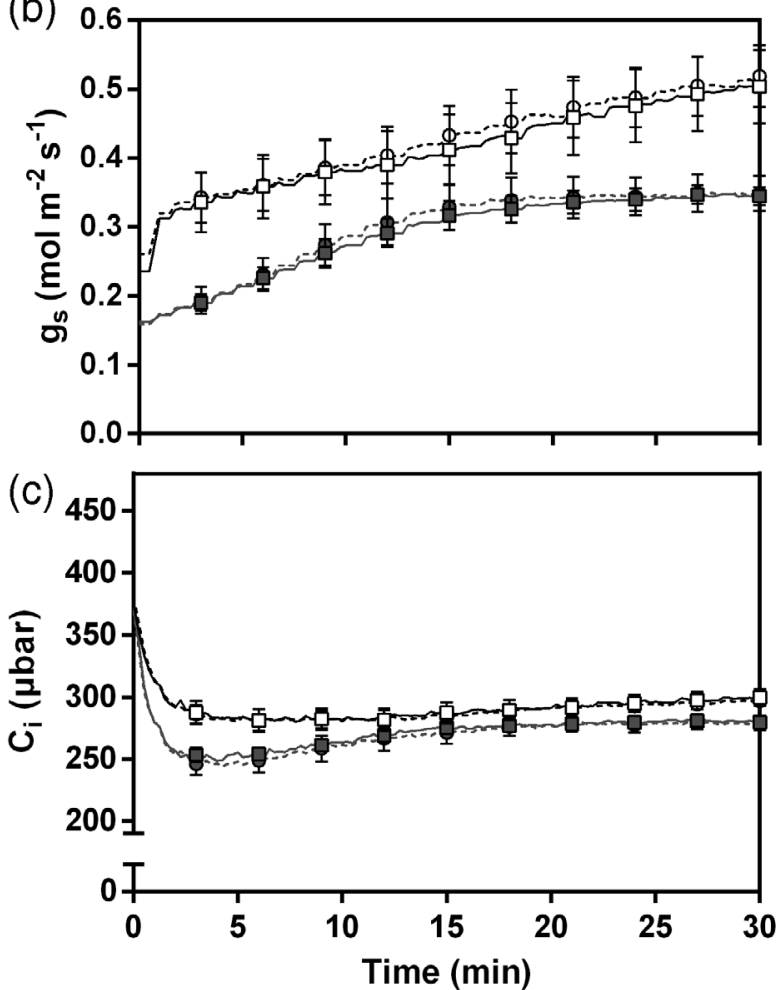

(d)
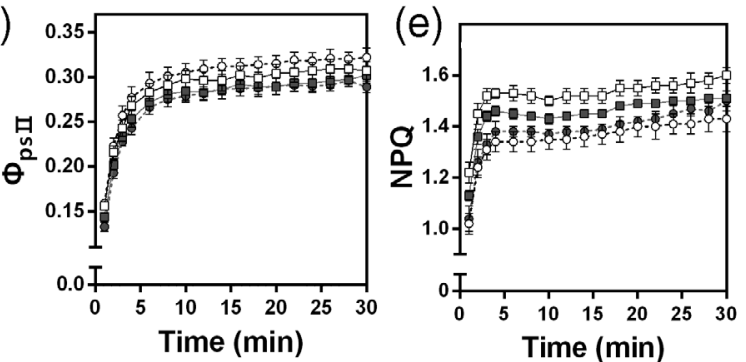

(f)
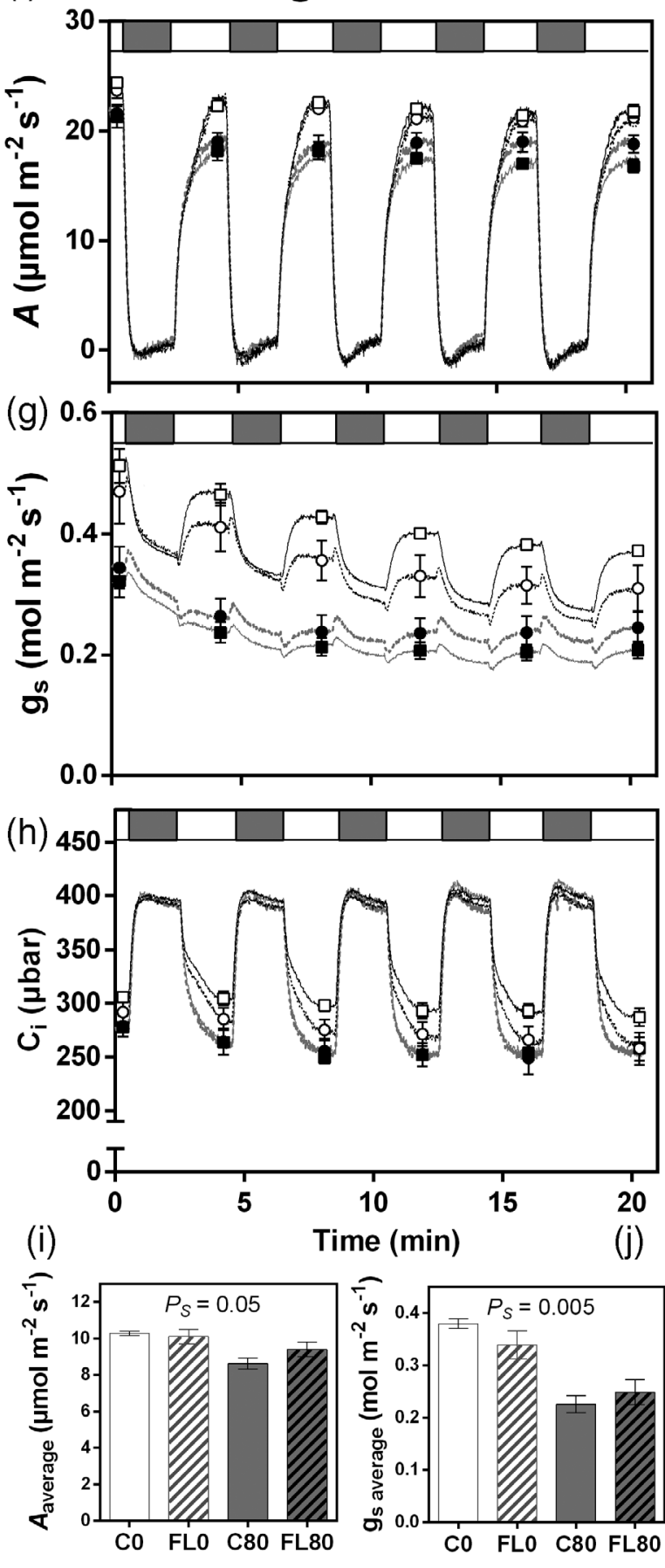

FIGURE 3 Dynamic photosynthetic responses to step changes in irradiance. Time course of leaf net photosynthesis rate (A; a), stomatal conductance $\left(g_{\mathrm{s}} ; \mathrm{b}\right)$, leaf internal $\mathrm{CO}_{2}$ partial pressure $\left(C_{\mathrm{i}} ; \mathrm{c}\right)$, photosystem II electron transport efficiency $\left(\Phi_{\mathrm{PSII}} ; \mathrm{d}\right)$ and non-photochemical fluorescence quenching (NPQ; e) when a leaf adapted to low irradiance $\left(50 \mu \mathrm{mol} \mathrm{m}^{-2} \mathrm{~s}^{-1}\right)$ was exposed to a sudden increase in irradiance to $1,500 \mu \mathrm{mol} \mathrm{m}^{-2} \mathrm{~s}^{-1}$. Time courses of $A(f), g_{s}(g), C_{i}(h)$ and the averages of $A$ and $g_{s}(i, j)$ to light fluctuations: high light $\left(1,500 \mu \mathrm{mol} \mathrm{m}^{-2} \mathrm{~s}^{-1}\right)$ adapted leaves were exposed to five repeated cycles of 2 min illumination of $50 \mu \mathrm{mol} \mathrm{m}^{-2} \mathrm{~s}^{-1}$ PPFD, followed by $2 \mathrm{~min}$ of $1,500 \mu \mathrm{mol} \mathrm{m} \mathrm{m}^{-2} \mathrm{~s}^{-1}$ PPFD. Shade- and lightflecks are visualized as grey and white bars, respectively. Plants were grown for 14 days under 4 treatments: CO (constant irradiance $+0 \mathrm{mM} \mathrm{NaCl}$ ), $\mathrm{FLO}$ (fluctuating irradiance $+0 \mathrm{mM} \mathrm{NaCl}$ ), $\mathrm{C} 80$ (constant irradiance $+80 \mathrm{mM} \mathrm{NaCl}$ ) and FL80 (fluctuating irradiance $+80 \mathrm{mM}$ $\mathrm{NaCl})$. Mean values \pm SEM of two to three independent experiments are shown $(n=2-3)$ and SEM can only be observed when larger than data point symbol. The main effect of salt stress was significant $(p<.05)$ at all time points in (a), (b) and (c). The main effect of light regime was significant $(p<.05)$ at all time points in (e). $p$-value of the main effect of salt stress $\left(P_{\mathrm{S}}\right)$ during lightflecks is shown in (i) and (j) 
TABLE 2 Leaf pigment and mineral concentrations

\begin{tabular}{|c|c|c|c|c|c|c|c|c|}
\hline & & \multicolumn{4}{|c|}{ Treatment } & \multicolumn{3}{|c|}{$p$-value } \\
\hline & & $\mathrm{CO}$ & FLO & $\mathrm{C} 80$ & FL80 & I & S & $\mathrm{I} \times \mathrm{S}$ \\
\hline \multirow[t]{5}{*}{ Pigments } & $\mathrm{Chl}\left(\mathrm{mg} \mathrm{m}^{-2}\right)$ & 618 & 587 & 614 & 578 & $<.001$ & .726 & .893 \\
\hline & $\mathrm{Chl}\left(\mathrm{mg} \mathrm{g}^{-1} \mathrm{FW}\right)$ & 1.786 & 1.777 & 1.715 & 1.738 & .795 & .181 & .678 \\
\hline & Chl $a: b$ & 3.81 & 3.80 & 3.82 & 3.78 & .192 & .930 & .749 \\
\hline & Cars $\left(\mathrm{mg} \mathrm{m}^{-2}\right)$ & 141 & 133 & 138 & 127 & .001 & .278 & .818 \\
\hline & Cars $\left(\mathrm{mg} \mathrm{g}^{-1} \mathrm{FW}\right)$ & 0.409 & 0.402 & 0.385 & 0.382 & .489 & .016 & .736 \\
\hline \multirow[t]{6}{*}{ Minerals } & $\mathrm{N}\left(\mathrm{g} \mathrm{m}^{-2}\right)$ & 1.87 & 1.78 & 1.75 & 1.63 & .021 & .052 & .801 \\
\hline & $\mathrm{N}\left(\mathrm{mg} \mathrm{g}^{-1} \mathrm{DW}\right)$ & 52.5 & 53.0 & 48.6 & 48.9 & .586 & .027 & .926 \\
\hline & $C\left(\mathrm{mg} \mathrm{g}^{-1} \mathrm{DW}\right)$ & 448.4 & 440.5 & 432.0 & 431.3 & .400 & .005 & .192 \\
\hline & $\mathrm{Na}^{+}\left(\mathrm{mg} \mathrm{g}^{-1} \mathrm{DW}\right)$ & 0.4 & 0.4 & 22.1 & 21.2 & .642 & $<.001$ & .828 \\
\hline & $\mathrm{K}^{+}\left(\mathrm{mg} \mathrm{g}^{-1} \mathrm{DW}\right)$ & 41.2 & 44.3 & 22.1 & 22.0 & .280 & .001 & .574 \\
\hline & $\mathrm{Na}^{+}: \mathrm{K}^{+}$ & 0.01 & 0.01 & 1.02 & 0.99 & .348 & .001 & .906 \\
\hline
\end{tabular}

Note: Tomato plants were grown for 14 days under four treatments: CO (constant irradiance $+0 \mathrm{mM}$ $\mathrm{NaCl}$ ), $\mathrm{FLO}$ (fluctuating irradiance $+0 \mathrm{mM} \mathrm{NaCl}$ ), $\mathrm{C} 80$ (constant irradiance $+80 \mathrm{mM} \mathrm{NaCl}$ ) and FL80 (fluctuating irradiance $+80 \mathrm{mM} \mathrm{NaCl}$ ). Chl, total chlorophyll $a$ and $b$ contents; $\mathrm{Chl} a: b$, chlorophyll $a: b$ ratio; Cars, total carotenoids content. Mean values of 3-4 independent experiments are shown ( $n=3-4)$, with 3-4 replicate plants per experiment. $p$-values of main effects of light pattern (I) and salt stress (S) and interaction effect $(I \times S)$ are shown, significant effects are printed bold.

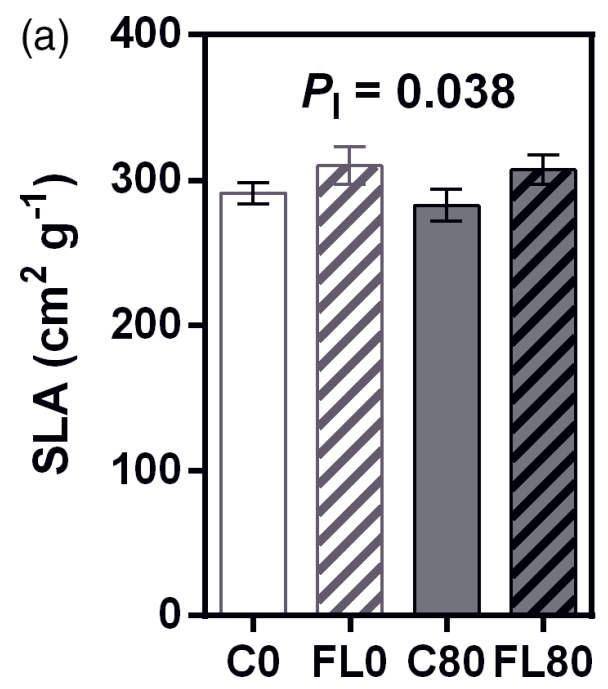

(b)
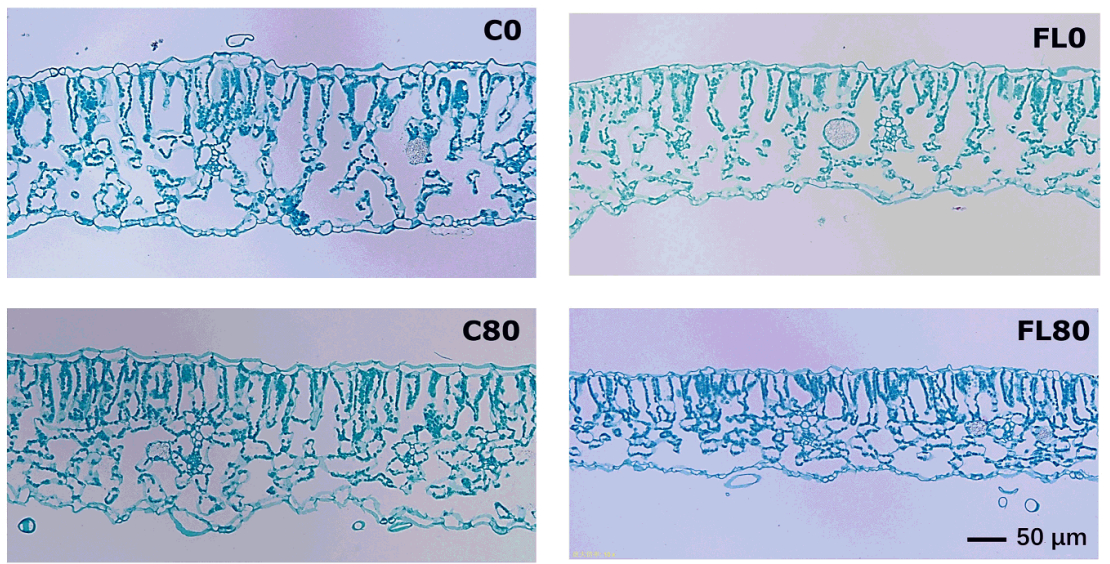

FIGURE 4 Specific leaf area (SLA, a) and representative images of leaf cross sections (b). Plants were grown for 14 days under four treatments: $\mathrm{CO}$ (constant irradiance $+0 \mathrm{mM} \mathrm{NaCl}$ ), FLO (fluctuating irradiance $+0 \mathrm{mM} \mathrm{NaCl}$ ), C 80 (constant irradiance $+80 \mathrm{mM} \mathrm{NaCl}$ ) and FL80 (fluctuating irradiance $+80 \mathrm{mM} \mathrm{NaCl})$. Mean values \pm SEM of SLA from five independent experiments are shown $(n=5)$. $P$-value of the main effect of light pattern $\left(P_{1}\right)$ is shown [Colour figure can be viewed at wileyonlinelibrary.com]

\subsection{1 | Species}

Photosynthetic acclimation to FL does not show a general response among species, and this might be related to differences in acclimation capacity besides photosynthetic physiology itself, for example, between sun- and shade plants (Poorter et al., 2019). Plant acclimation to FL has been studied on sun-demanding species, including Arabidopsis (Alter et al., 2012; Elias Kaiser, Walther, \& Armbruster, 2020;Matthews et al., 2018 ; Vialet-Chabrand et al., 2017) and tomato (E. Kaiser et al., 2018), as well as on woody understory species, including Shorea leprosula (Leakey et al., 2002), Alocasia macrorrhiza (Sims \& Pearcy, 1993) and four Australian rain-forest species (Watling, Ball, \& Woodrow, 1997). When acclimating to FL, leaves of sun-demanding plants changed leaf thickness (E. Kaiser et al., 2018; Vialet-Chabrand et al., 2017), chlorophyll concentration (Alter et al., 2012) and chlorophyll $a: b$ ratio (chl $a: b$ ) (Vialet-Chabrand et al., 2017), while in shade tolerant and woody plants these traits hardly changed (Leakey et al., 2002; Sims \& Pearcy, 1993; Watling et al., 1997). This is consistent with the notion that shade tolerant and woody plants have lower plasticity than sun-demanding species (Murchie \& Horton, 1997; Poorter et al., 2019).

Tomato and Arabidopsis are commonly used model plants. The most extensive work on Arabidopsis acclimation to FL was performed 


\begin{tabular}{|c|c|c|c|c|c|c|c|c|}
\hline & & \multicolumn{4}{|c|}{ Treatment } & \multicolumn{3}{|c|}{$p$-value } \\
\hline & & $\mathrm{CO}$ & FLO & $\mathrm{C} 80$ & FL80 & I & $S$ & $I \times S$ \\
\hline \multirow{2}{*}{$\begin{array}{l}\text { Stomatal density (no. } \\
\mathrm{mm}^{-2} \text { ) }\end{array}$} & Adaxial & 88 & 70 & 44 & 39 & .033 & .049 & .563 \\
\hline & Abaxial & 210 & 205 & 156 & 151 & .442 & .136 & 1.000 \\
\hline \multirow[t]{2}{*}{ Stomatal index } & Adaxial & 0.16 & 0.14 & 0.10 & 0.09 & .336 & .011 & .350 \\
\hline & Abaxial & 0.35 & 0.34 & 0.28 & 0.28 & .702 & .021 & .768 \\
\hline \multirow[t]{2}{*}{ Stomatal area $\left(\mu \mathrm{m}^{2}\right)$} & Adaxial & 406 & 403 & 333 & 342 & .840 & .025 & .622 \\
\hline & Abaxial & 445 & 421 & 345 & 350 & .395 & .034 & .474 \\
\hline \multirow[t]{2}{*}{ Pore aperture $(\mu \mathrm{m})$} & Adaxial & 2.1 & 2.4 & 1.8 & 2.1 & .447 & .054 & .756 \\
\hline & Abaxial & 5.8 & 5.0 & 3.6 & 3.9 & .706 & .094 & .405 \\
\hline \multirow{2}{*}{$\begin{array}{l}\text { Pore area per leaf area } \\
\qquad\left(\mu \mathrm{m}^{2} \mathrm{~mm}^{-2}\right)\end{array}$} & Adaxial & 2,548 & 2,479 & 1,044 & 1,092 & .958 & .023 & .819 \\
\hline & Abaxial & 17,864 & 14,493 & 7,131 & 7,398 & .475 & .066 & .530 \\
\hline
\end{tabular}

Note: Tomato plants were grown for 14 days under four treatments: $\mathrm{CO}$ (constant irradiance $+0 \mathrm{mM}$ $\mathrm{NaCl}$ ), FLO (fluctuating irradiance $+0 \mathrm{mM} \mathrm{NaCl}$ ), $\mathrm{C} 80$ (constant irradiance $+80 \mathrm{mM} \mathrm{NaCl}$ ) and FL80 (fluctuating irradiance $+80 \mathrm{mM} \mathrm{NaCl}$ ). Stomatal density, number of stomata per unit leaf area; stomatal index, number of stomata relative to the number of epidermal cells; stomatal area, average area per stomata; pore aperture, average width of the stomatal pore. Mean values of two independent experiments are shown $(n=2)$, with 3-4 replicate plants per experiment. $p$-values of main effects of light pattern (I) and salt stress $(\mathrm{S})$ and interaction effect $(\mathrm{I} \times \mathrm{S})$ are shown, significant effects are printed bold.
TABLE 3 Stomatal traits on the adaxial and abaxial surfaces of tomato leaves by Lawson and co-workers (Matthews et al., 2018; Vialet-Chabrand et al., 2017). Work on tomato acclimation to FL other than the present study was reported by Kaiser et al. (2018). Although results came from different research groups using different FL patterns and experimental procedures, broadly, our analysis suggests that Arabidopsis might have a higher plasticity to FL than tomato: Firstly, leaves were thinner under FL in both, but this decrease was larger in Arabidopsis (approximately 30\%; Vialet-Chabrand et al., 2017) than tomato (16\% in our study, Figure 4; 3\% in Kaiser et al., 2018). Secondly, the chl $a: b$, representing chloroplast-level acclimation, was significantly lower, in FL grown leaves of Arabidopsis (Vialet-Chabrand et al., 2017) while in tomato (our study), FL did not change the chl $a: b$, but reduced both chlorophylls (Table 2). Photosynthetic capacity, expressed as $A_{\max }$, was unaffected by FL in either species. However, Arabidopsis acclimated to FL showed reductions in concentrations of photosynthetic electron transport proteins, indicating a lower investment in leaf photosynthetic processes (Vialet-Chabrand et al., 2017) while in tomato, $J$ (Figure 2) and abundance of related proteins (Figure S6) were unaffected. Besides, acclimation to FL affected the diurnal rhythm of $g_{s}$ and the rapidity of response of $g_{s}$ to changes in light intensity in Arabidopsis (Matthews et al., 2018), while in tomato, no effects on $g_{s}$ dynamics were found (Figure 3; Kaiser et al., 2018).

\subsection{2 | Light regime}

The various FL regimes used in previous studies may have affected the extent of FL acclimation, as this could be affected by light intensity amplitudes, lightfleck frequencies and durations, along with light spectrum (Morales \& Kaiser, 2020). Our FL regime contained nonstressful peak light intensities of $650 \mu \mathrm{mol} \mathrm{m} \mathrm{m}^{-2} \mathrm{~s}^{-1}$. Plants under FL showed mostly shade-type acclimation, including high SLA (Figure 4) and low NPQ (Figure 3e, Table 1). This could be because during two thirds of the photoperiod in $\mathrm{FL}$, light intensity was below that of $\mathrm{C}$ (200 $\mu \mathrm{mol} \mathrm{m} \mathrm{m}^{-2} \mathrm{~s}^{-1}$, Figure 1). This low light proportion may have had larger effects than the high light proportion of our FL pattern on overall light acclimation. In Arabidopsis, leaves grown under FL showed high NPQ and fast NPQ buildup (Alter et al., 2012), a high-light acclimation trait. This might be explained by frequent, repeated and strong lightflecks in the FL pattern by Alter et al. (2012), where lightflecks were $>7 \times$ higher than $C$. In our study, the peak light intensity was 3.3 fold higher than $C$, and was applied once per day, which may not have increased photoprotective capacity compared to C. Likely, differences in high and low light amplitude and duration trigger differences in signalling, impinging on nuclear gene expression and subsequent protein abundance that are associated with dynamic acclimation to $\mathrm{FL}$ (Dietz, 2015). A recent modelling study tried to disentangle the effects of FL frequency and duration (Retkute et al., 2015), but only few experimental data were available to support its findings. How low and high light amplitudes, lightfleck frequencies and durations affect photosynthetic acclimation still awaits experimental verification.

\section{2 | Salt stress downregulates photosynthesis regardless of light regime}

Salt stress usually decreases photosynthesis (Shu et al., 2014; Tounekti, Abreu, Khemira, \& Munné-Bosch, 2012; Zhang et al., 2018), but these effects vary with dose and species (Wungrampha, Joshi, Singla-Pareek, \& Pareek, 2018; Zorb, Geilfus, \& Dietz, 2019). Here, the strongest effects of salt stress on photosynthesis were a decrease in $\mathrm{g}_{\mathrm{s}}$ (Figure $2 \mathrm{c}$ and $3 \mathrm{~b}, \mathrm{~g}$ ) and alterated chloroplast ultrastructure (Figure S5). $g_{s}$ was reduced as a result of low stomatal density and area (Table 3), decreasing A especially under high light 


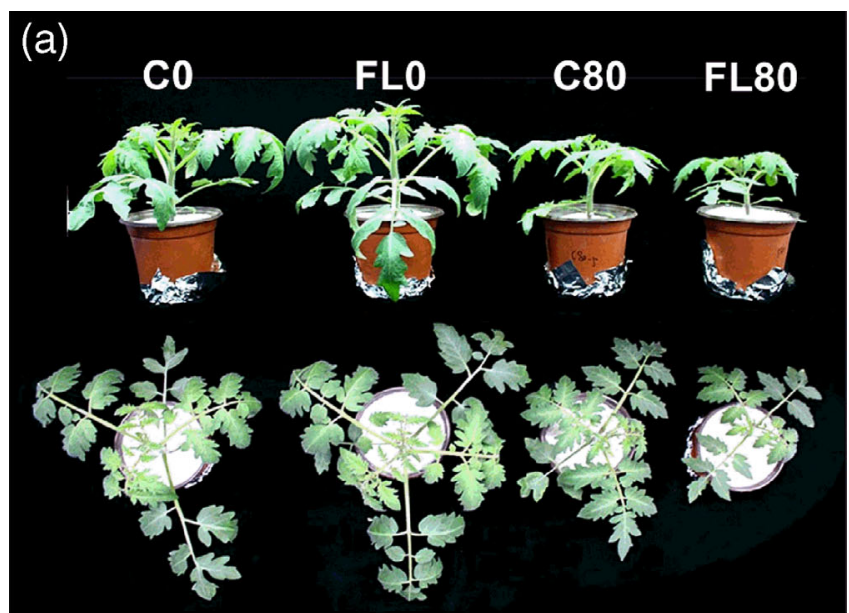

(b)

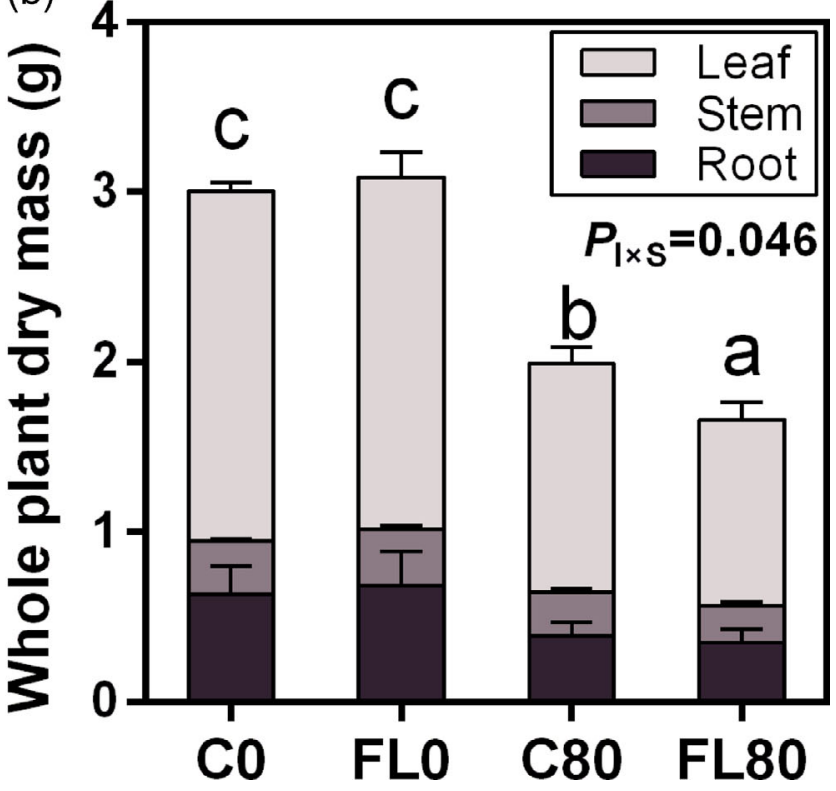

FIGURE 5 Plant growth and biomass. (a) Representative images showing tomato plants which were grown for 14 days under four treatments: $\mathrm{CO}$ (constant irradiance $+0 \mathrm{mM} \mathrm{NaCl}$ ), FLO (fluctuating irradiance $+0 \mathrm{mM} \mathrm{NaCl}$ )), $\mathrm{C} 80$ (constant irradiance $+80 \mathrm{mM} \mathrm{NaCl}$ ) and FL80 (fluctuating irradiance $+80 \mathrm{mM} \mathrm{NaCl}$ ). (b) Whole plant dry mass after 14 days of treatment. Mean values \pm SEM from five independent experiments are shown $(n=5)$. The $p$-value of the interaction effect of light pattern and salt stress $\left(P_{I \times S}\right)$ on total biomass is shown. Different letters denote significant treatment effects on total biomass $(p<.05)$ [Colour figure can be viewed at wileyonlinelibrary.com]

$\left(>1,000 \mu \mathrm{mol} \mathrm{m} \mathrm{m}^{-2} \mathrm{~s}^{-1}\right)$. Notably, our relatively modest light intensity fluctuations and salt stress did not interactively affect photosynthetic acclimation $\left(P_{1 \times S}>0.05\right.$, Table 1$)$. Under an FL regime with a more extreme light intensity range, interactions with salt stress may occur, as high light (photooxidative stress) and salt stress signalling can overlap (Yang \& Guo, 2018). For example, abscisic acid is a player in high light and salt acclimation (Dietz, 2015; Tardieu, Parent, \& Simonneau, 2010), and could affect stomatal development, stomatal mechanics and leaf gas exchange (Franks \& Farquhar, 2001).

\subsection{Without salt stress, biomass is unaffected by fluctuating irradiance}

Biomass is often significantly reduced by fluctuations of irradiance, on average by $32 \%$ across studies, although with large variability (E. Kaiser et al., 2018; Kubásek et al., 2013; Leakey et al., 2002; Morales \& Kaiser, 2020; Vialet-Chabrand et al., 2017; Watling et al., 1997). Reduction in growth under FL can be expected from the perspective of leaf photosynthesis, as $A$ lags behind stepwise increases in light intensity (Figure $3 a$ ) much more strongly than it lags behind stepwise decreases (Figure 3f), decreasing the light use efficiency under FL compared to the steady state. Also, under FL, leaves are exposed to high irradiance for a part of the photoperiod. At the leaf level, higher irradiance is used with a lower quantum efficiency than that of most constant light treatments, due to a nonlinear response of steady-state leaf photosynthesis to irradiance (Figure 2a).

However, in our study, total plant biomass was unaffected by FL in the absence of salt stress (Figure 5). This could partly be explained from the perspective of leaf photosynthesis. Firstly, in this study, under FL there were approximately 90 stepwise increases in light intensity during the photoperiod, and these were $\sim 54 \mu \mathrm{mol} \mathrm{m}^{-2} \mathrm{~s}^{-1}$ on average (Figure 1). Therefore, the losses due slow transient increases of photosynthesis could be relatively minor, as these stepwise increases were mild and light intensity after stepwise decreases was not very low (i.e., photosynthetic induction was often not strongly reduced after reductions in light intensity). In many FL studies, FL light intensity was frequently switched from a low to a high level with a large stepwise increase (e.g., $>600 \mu \mathrm{mol} \mathrm{m}{ }^{-2} \mathrm{~s}^{-1}$ in Alter et al., 2012; Kaiser et al., 2018), which should impact more negatively on light use efficiency under FL, compared to the pattern used here (Figure 1). Secondly, based on the steady-state photosynthesis irradiance response (Figure 2a), leaf net photosynthesis rate per day $\left(A_{\text {day }}\right)$ would decrease by $9 \%$ under FL compared to C (Figure 2a). This $9 \%$ reduction is especially relevant for the uppermost leaves in the canopy; for lower leaves, which are partly shaded by upper leaves, this effect is smaller (Marcelis \& De Pascale, 2009). Hence, at the whole plant this effect is likely smaller, which may partly explain why plant growth was not affected by FL.

Another possible reason that total plant biomass was unaffected by $F L$ in the absence of salt stress could be related to changes in leaf mophology upon FL (Figure 5): FL reduced leaf thickness (Figure 4; Kaiser et al., 2018) and tended to increase leaf area (Table 3) to increase whole-plant light interception to compensate for the reduction in photosynthesis per unit leaf area $\left(A_{\text {day }}\right.$, Figure 6). Leaves can modulate the area per unit biomass, by altering their thickness (Evans \& Poorter, 2001). Leaf biomass was spread over a larger area of thinner leaves under FL, resulting in significantly larger light capture per unit biomass (7\% increase in SLA, Table 4) in FL than in C. Increased light capture under FL may thus have compensated for the reduction of photosynthesis per unit leaf area, resulting in a similar biomass compared to plants under $\mathrm{C}$ (Figure 6). 
TABLE 4 Growth traits of whole plants

\begin{tabular}{|c|c|c|c|c|c|c|c|c|}
\hline & & \multicolumn{4}{|c|}{ Treatment } & \multicolumn{3}{|c|}{$p$-value } \\
\hline \multirow[t]{5}{*}{ Leaf } & Leaf number (>10 cm) & 6.13 & 6.07 & 5.43 & 4.95 & .017 & $<.001$ & .202 \\
\hline & Fresh weight (g) & 20.9 & 21.4 & 13.8 & 11.4 & .226 & $<.001$ & .056 \\
\hline & Dry weight (g) & 2.06 & 2.07 & 1.34 & 1.09 & .119 & $<.001$ & .071 \\
\hline & Area $\left(\mathrm{cm}^{2}\right)$ & $597 \mathrm{~b}$ & $633 \mathrm{~b}$ & $374 a$ & 332 a & & & .012 \\
\hline & Dry matter content (\%) & 9.9 & 9.7 & 9.7 & 9.5 & .478 & .331 & .768 \\
\hline \multirow[t]{3}{*}{ Stem } & Length $(\mathrm{cm})$ & 12.9 & 13.4 & 11.5 & 10.9 & .72 & $<.001$ & .076 \\
\hline & Fresh weight (g) & 5.1 & 5.4 & 3.8 & 3.2 & .495 & $<.001$ & .054 \\
\hline & Dry weight (g) & 0.31 & 0.33 & 0.26 & 0.22 & .251 & $<.001$ & .066 \\
\hline Shoot & Dry weight (g) & 2.37 & 2.40 & 1.60 & 1.31 & .129 & $<.001$ & .062 \\
\hline \multirow[t]{2}{*}{ Root } & Dry weight (g) & 0.64 & 0.69 & 0.39 & 0.35 & .811 & .004 & .558 \\
\hline & Shoot: root & 4.4 & 4.2 & 4.5 & 4.1 & .014 & .953 & .666 \\
\hline
\end{tabular}

Note: Tomato plants were grown for 14 days under four treatments: $\mathrm{CO}$ (constant irradiance $+0 \mathrm{mM} \mathrm{NaCl}$ ), FLO (fluctuating irradiance $+0 \mathrm{mM} \mathrm{NaCl),} \mathrm{C80}$ (constant irradiance $+80 \mathrm{mM} \mathrm{NaCl}$ ) and $\mathrm{FL} 80$ (fluctuating irradiance $+80 \mathrm{mM} \mathrm{NaCl}$ ). Mean values of five independent experiments are shown ( $\mathrm{n}=5$ ), with 3-4 replicate plants per round of experiment. $p$-values of main effects of light pattern (I) and salt stress $(\mathrm{S})$ and interaction effect $(\mathrm{I} \times \mathrm{S})$ are shown, significant effects are printed bold. Significant differences are indicated by different letters.

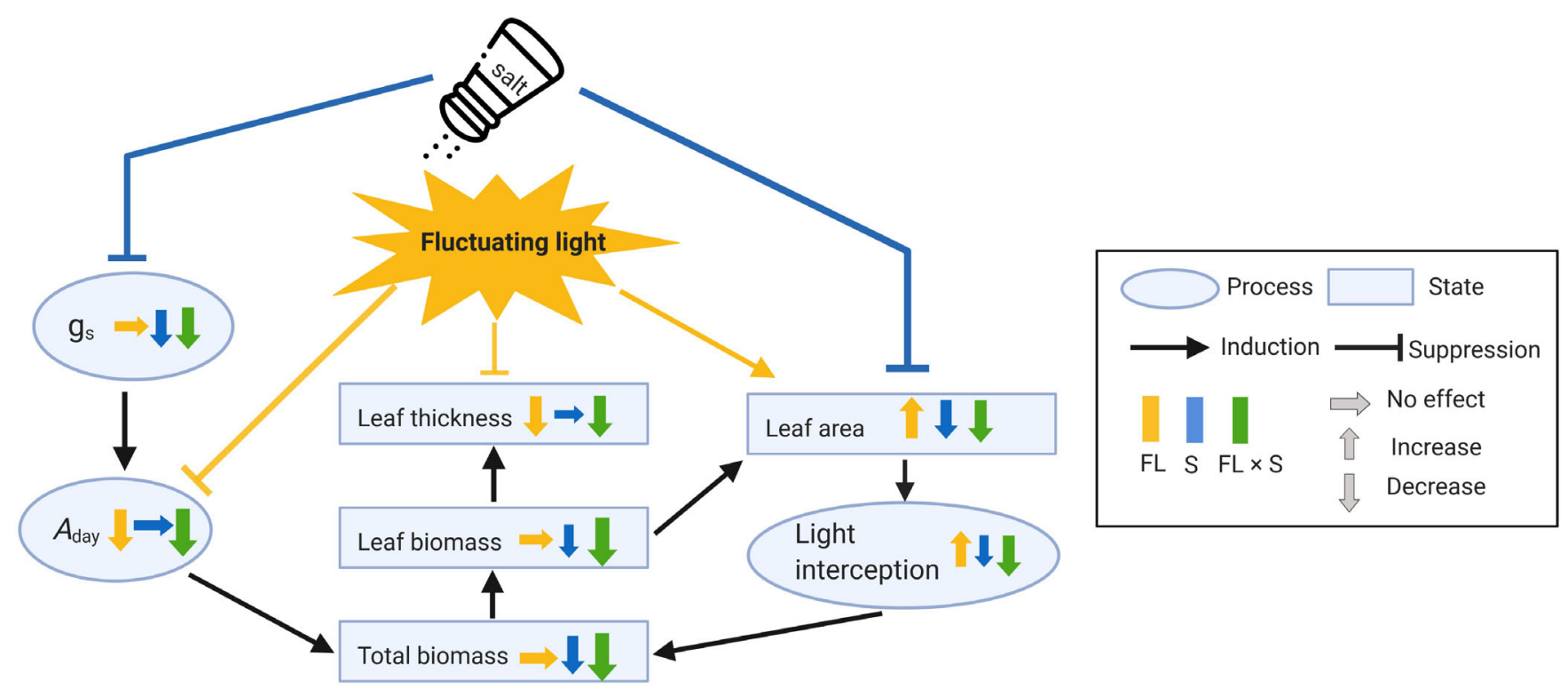

FIGURE 6 Major effects of fluctuating light $(\mathrm{FL})$, salt stress $(\mathrm{S})$ and their combination $(\mathrm{FL} \times \mathrm{S})$ on plant growth, relative to the C0 treatment (i.e., absence of fluctuating light and salt stress). $A_{\text {day }}$, diurnally integrated net photosynthesis rate per unit leaf area; $g_{s}$, stomatal conductance [Colour figure can be viewed at wileyonlinelibrary.com]

\subsection{Under salt stress, biomass is reduced by fluctuating irradiance}

Salt stress generally inhibits plant growth (Munns \& Tester, 2008), but the extent of inhibition can depend on the growth light condition: salt stress decreased biomass more strongly under FL than under $C$ (Figure 5). Under $C$, the growth reduction under salt stress may have been mainly due to diminished leaf area, caused by a reduction in both leaf initiation and expansion (Table 4) (Munns \& Tester, 2008), rather than due to a reduction in photosynthesis. Indeed, under a constant 
$200 \mu \mathrm{mol} \mathrm{m} \mathrm{m}^{-2} \mathrm{~s}^{-1}$, A was not significantly reduced in salt-stressed leaves (Figure 2a). Below, we reason that in salt stressed plants, the additional $17 \%$ reduction of biomass due to FL (FL80 vs. C80) could be due to reduced $A_{\text {day }}$, reduced leaf area, or their combination.

Without salt stress, $A_{\text {day }}$ under FL was probably only marginally reduced (see above). However, under salt stress, that reduction could be larger: firstly, similarly to non-stressed plants, due to the steadystate leaf photosynthesis irradiance relationship (Figure 2a), $A_{\text {day }}$ of salt-stressed leaves may have decreased by $10 \%$ under FL compared to $C$, and that decrease was slightly larger than in unstressed leaves (9\%). Secondly, salt stress strongly decreased $g_{s}$ (Figures $2 c$ and $3 b$ ), possibly additionally reducing $A_{\text {day }}$ under FL relative to $\mathrm{C}$, as the temporal response of $g_{\mathrm{s}}$ is a key limitation of photosynthesis under $\mathrm{FL}$ (Pearcy et al., 1996). This reduction in $g_{s}$ did not seem to limit photosynthesis under $C$ (Figure 2a, $A$ at $200 \mu \mathrm{mol} \mathrm{m}^{-2} \mathrm{~s}^{-1}$ ). During a series of lightflecks, salt stress reduced $g_{s}$ by approxiamtely $30 \%$ (Figure $3 g$, j), and reduced $A$ by $12 \%$ compared to unstressed leaves under lightflecks (Figure $3 \mathrm{i}$ ). Had a constant light intensity been applied with the same average intensity as during the lightflecks (PPFD of approximately $775 \mu \mathrm{mol} \mathrm{m}{ }^{-2} \mathrm{~s}^{-1}$ ), average $A$ would have been approximately $20.7 \mu \mathrm{mol} \mathrm{m}{ }^{-2} \mathrm{~s}^{-1}$ in non-stressed and $\sim 19.6 \mu \mathrm{mol} \mathrm{m}^{-2} \mathrm{~s}^{-1}$ in saltstressed leaves (Figure 2a). Hence, the difference between average A under lightflecks and under constant light would be $54 \%$ (i.e., C80 vs. FL80) in salt-stressed leaves, which was larger than that in unstressed leaves (50\%, i.e., CO vs. FLO). Although not the same as the FL growth pattern, the lightfleck experiment in Figure $3 \mathrm{f}-\mathrm{j}$ showcases that the reduction in $A$ between $F L$ and $C$ treatments in salt-stressed plants could be larger than in unstressed plants. Thirdly, at the whole plant level, salt-stressed plants were much smaller than unstressed plants (Figure 5), which means there were fewer shaded leaves compared to unstressed plants. Hence, a larger fraction of leaf area was directly exposed to light intensity fluctuations which-as stated above-may have reduced $A_{\text {day }}$ per unit leaf area in salt-stressed plants.

The combination of salt stress and FL seemed to reduce the rate of development, as suggested by a significant reduction in the number of leaves in F80 relative to $\mathrm{C} 80$ ( $9 \%$, Table 4). The reduction in leaf number in salt-stressed plants by FL likely reduced total leaf area ( $11 \%$ reduction in $\mathrm{F} 80$ relative to $\mathrm{C} 80$, Table 4 ) and thus whole-plant light interception compared to plants under $\mathrm{C}$, likely resulting in a lower plant growth rate.

\section{5 | CONCLUSIONS}

Our study shows that salt stress and fluctuating light have separate effects on leaf photosynthetic acclimation, but interactive effects on plant growth. The results of the present study suggest that growing plants under laboratory conditions and constant irradiance may not accurately represent plant acclimation and development under a natural environment. Growing plants under a constant light intensity may easily underestimate salt-induced decreases of plant growth under fluctuating light, by $17 \%$.

\section{ACKNOWLEDGEMENTS}

The authors acknowledge the financial support by the National Natural Science Foundation of China (No. 31872955, 31501808), the National Key Research and Development Program of China (2017YFB0403902), the Central Public-interest Scientific Institution Basal Research Fund (No. BSRF201911) and the 4TU programme "PLANTENNA: Botanic sensor networks, towards an Internet of Plants". We thank Prof. Wenbin Zhou (Chinese Academy of Agricultural Sciences, China) for the guidance of protein extraction and western blotting. We thank Dr. Ep Heuvelink (Wageningen University, the Netherlands) for the guidance of statistical analysis. We also thank Dr. Zhengwei Zhang (Chinese Academy of Agricultural Sciences, China) for the help of plant growth measurements.

\section{CONFLICT OF INTEREST}

The authors declare no conflict of interest.

\section{ORCID}

Yuqi Zhang (D) https://orcid.org/0000-0003-1431-7407

Elias Kaiser (D) https://orcid.org/0000-0002-9081-9604

Leo F. M. Marcelis (D) https://orcid.org/0000-0002-8088-7232

\section{REFERENCES}

Alter, P., Dreissen, A., Luo, F. L., \& Matsubara, S. (2012). Acclimatory responses of Arabidopsis to fluctuating light environment: Comparison of different sunfleck regimes and accessions. Photosynthesis Research, 113(1-3), 221-237. https://doi.org/10.1007/s11120-012-9757-2

Bradford, M. M. (1976). A rapid and sensitive method for the quantitation of microgram quantities of protein utilizing the principle of proteindye binding. Analytical Biochemistry, 72(1-2), 248-254.

Caliandro, R., Nagel, K. A., Kastenholz, B., Bassi, R., Li, Z., Niyogi, K. K., ... Matsubara, S. (2013). Effects of altered alpha- and beta-branch carotenoid biosynthesis on photoprotection and whole-plant acclimation of Arabidopsis to photo-oxidative stress. Plant, Cell \& Environment, 36(2), 438-453. https://doi.org/10.1111/j.1365-3040.2012.02586.x

Cannell, M., G, R., Thornley, J., \& G, M. (1998). Temperature and $\mathrm{CO}_{2}$ responses of leaf and canopy photosynthesis: A clarification using the non-rectangular hyperbola model of photosynthesis. Annals of Botany, 82(6), 883-892.

Chaves, M. M., Costa, J. M., \& Saibo, N. J. (2011). Recent advances in photosynthesis under drought and salinity. In Plant responses to drought and salinity stress-Developments in a post-genomic era (Vol. 57, pp. 49-104). USA: Elsevier.

Chen, T. W., Stutzel, H., \& Kahlen, K. (2018). High light aggravates functional limitations of cucumber canopy photosynthesis under salinity. Annals of Botany, 121, 797-807. https://doi.org/10.1093/aob/ mcx100

Debouba, M., Gouia, H., Suzuki, A., \& Ghorbel, M. H. (2006). NaCl stress effects on enzymes involved in nitrogen assimilation pathway in tomato "Lycopersicon esculentum" seedlings. Journal of Plant Physiology, 163(12), 1247-1258. https://doi.org/10.1016/j.jplph.2005. 09.012

Dietz, K. J. (2015). Efficient high light acclimation involves rapid processes at multiple mechanistic levels. Journal of Experimental Botany, 66(9), 2401-2414. https://doi.org/10.1093/jxb/eru505

Evans, J. R., \& Poorter, H. (2001). Photosynthetic acclimation of plants to growth irradiance: The relative importance of specific leaf area and nitrogen partitioning in maximizing carbon gain. Plant, Cell \& Environment, 24(8), 755-767. 
Flexas, J., Díaz-Espejo, A., Berry, J. A., Cifre, J., Galmés, J., Kaldenhoff, R., ... Ribas-Carbó, M. (2007). Analysis of leakage in IRGA's leaf chambers of open gas exchange systems: Quantification and its effects in photosynthesis parameterization. Journal of Experimental Botany, 58(6), 1533-1543. https://doi.org/10.1093/jxb/erm027

Franks, P. J., \& Farquhar, G. D. (2001). The effect of exogenous abscisic acid on stomatal development, stomatal mechanics, and leaf gas exchange in Tradescantia virginiana. Plant Physiology, 125(2), 935-942.

Harley, P. C., Loreto, F., di Marco, G., \& Sharkey, T. D. (1992). Theoretical considerations when estimating the mesophyll conductance to $\mathrm{CO} 2$ flux by analysis of the response of photosynthesis to CO2. Plant Physiology, 98(4), 1429-1436.

Hoshino, R., Yoshida, Y., \& Tsukaya, H. (2019). Multiple steps of leaf thickening during sun-leaf formation in Arabidopsis. The Plant Journal, 100 (4), 738-753.

Kaiser, E., Kromdijk, J., Harbinson, J., Heuvelink, E., \& Marcelis, L. F. (2017). Photosynthetic induction and its diffusional, carboxylation and electron transport processes as affected by $\mathrm{CO}_{2}$ partial pressure, temperature, air humidity and blue irradiance. Annals of Botany, 119(1), 191-205. https://doi.org/10.1093/aob/mcw226

Kaiser, E., Matsubara, S., Harbinson, J., Heuvelink, E., \& Marcelis, L. F. M. (2018). Acclimation of photosynthesis to lightflecks in tomato leaves: Interaction with progressive shading in a growing canopy. Physiologia Plantarum, 162(4), 506-517.

Kaiser, E., Morales, A., Harbinson, J., Heuvelink, E., Prinzenberg, A. E., \& Marcelis, L. F. (2016). Metabolic and diffusional limitations of photosynthesis in fluctuating irradiance in Arabidopsis thaliana. Scientific Reports, 6, 31252. https://doi.org/10.1038/srep31252

Kaiser, E., Walther, D., \& Armbruster, U. (2020). Growth under fluctuating light reveals large trait variation in a panel of Arabidopsis accessions. Plants, 9(3), 316. https://doi.org/10.3390/plants9030316

Kubásek, J., Urban, O., \& Santrucek, J. (2013). C4 plants use fluctuating light less efficiently than do C3 plants: A study of growth, photosynthesis and carbon isotope discrimination. Physiologia Plantarum, 149 (4), 528-539. https://doi.org/10.1111/ppl.12057

Lanoue, J., Zheng, J., Little, C., Thibodeau, A., Grodzinski, B., \& Hao, X. (2019). Alternating red and blue light-emitting diodes allows for injuryfree tomato production with continuous lighting. Frontiers in Plant Science, 10, 1114. https://doi.org/10.3389/fpls.2019.01114

Leakey, A., Press, M. C., Scholes, J., \& Watling, J. (2002). Relative enhancement of photosynthesis and growth at elevated $\mathrm{CO} 2$ is greater under sunflecks than uniform irradiance in a tropical rain forest tree seedling. Plant, Cell \& Environment, 25(12), 1701-1714.

Lichtenthaler, H. K., \& Buschmann, C. (2001). Chlorophylls and carotenoids: Measurement and characterization by UV-VIS spectroscopy. Current Protocols in Food Analytical Chemistry, 1, F4.3.1-F4.3.8.

Loriaux, S. D., Avenson, T. J., Welles, J. M., McDermitt, D. K., Eckles, R. D., Riensche, B., \& Genty, B. (2013). Closing in on maximum yield of chlorophyll fluorescence using a single multiphase flash of sub-saturating intensity. Plant, Cell and Environment, 36(10), 1755-1770. https://doi. org/10.1111/pce.12115

Marcelis, L., \& De Pascale, S. (2009). Crop management in greenhouses: adapting the growth conditions to the plant needs or adapting the plant to the growth conditions? Acta Horticulturae, 807, 163-174 https://doi.org/10.17660/ActaHortic.2009.807.20.

Matthews, J. S., Vialet-Chabrand, S. R., \& Lawson, T. (2018). Acclimation to fluctuating light impacts the rapidity and diurnal rhythm of stomatal conductance. Plant Physiology, 176(3), 1939-1951. https://doi.org/10. 1104/pp.17.01809

Morales, A., \& Kaiser, E. (2020). Photosynthetic acclimation to fluctuating irradiance in plants. Frontiers in Plant Science, 11, 268. https://doi.org/ 10.3389/fpls.2020.00268.

Mulholland, B. J., Taylor, I. B., Jackson, A. C., \& Thompson, A. J. (2003). Can ABA mediate responses of salinity stressed tomato. Environmental and Experimental Botany, 50(1), 17-28. https://doi.org/10.1016/ s0098-8472(02)00110-7

Munns, R., \& Tester, M. (2008). Mechanisms of salinity tolerance. Annual Review of Plant Biology, 59, 651-681. https://doi.org/10.1146/ annurev.arplant.59.032607.092911

Murchie, E. H., \& Horton, P. (1997). Acclimation of photosynthesis to irradiance and spectral quality in British plant species: Chlorophyll content, photosynthetic capacity and habitat preference. Plant, Cell \& Environment, 20(4), 438-448.

Murchie, E. H., Kefauver, S., Araus, J. L., Muller, O., Rascher, U. Flood, P. J., \& Lawson, T. (2018). Measuring the dynamic photosynthome. Annals of Botany, 122(2), 207-220. https://doi.org/10. 1093/aob/mcy087

Niinemets, U. (2007). Photosynthesis and resource distribution through plant canopies. Plant, Cell \& Environment, 30(9), 1052-1071. https:// doi.org/10.1111/j.1365-3040.2007.01683.x

Niinemets, U., \& Valladares, F. (2004). Photosynthetic acclimation to simultaneous and interacting environmental stresses along natural light gradients: Optimality and constraints. Plant Biology, 6(3), 254-268. https://doi.org/10.1055/s-2004-817881

Pao, Y. C., Stutzel, H., \& Chen, T. W. (2019). A mechanistic view of the reduction in photosynthetic protein abundance under diurnal light fluctuation. Journal of Experimental Botany, 70(15), 3705-3708. https://doi.org/10.1093/jxb/erz164

Pearcy, R. W. (1990). Sunflecks and photosynthesis in plant canopies. Annual Review of Plant Physiology, 41(1), 421-453.

Pearcy, R. W., Krall, J. P., \& Sassenrath, G. F. (1996). Photosynthesis in fluctuating light environments. In N. R. Baker (Ed.), Photosynthesis and the environment (pp. 321-346). The Netherlands: Springer.

Poorter, H., Fiorani, F., Pieruschka, R., Wojciechowski, T., van der Putten, W. H., Kleyer, M., ... Postma, J. (2016). Pampered inside, pestered outside? Differences and similarities between plants growing in controlled conditions and in the field. New Phytologist, 212(4), 838-855. https://doi.org/10.1111/nph.14243

Poorter, H., Niinemets, U., Ntagkas, N., Siebenkas, A., Maenpaa, M., Matsubara, S., \& Pons, T. (2019). A meta-analysis of plant responses to light intensity for 70 traits ranging from molecules to whole plant performance. New Phytologist, 223, 1073-1105. https://doi.org/10. 1111/nph.15754

Retkute, R., Smith-Unna, S. E., Smith, R. W., Burgess, A. J., Jensen, O. E., Johnson, G. N., ... Murchie, E. H. (2015). Exploiting heterogeneous environments: Does photosynthetic acclimation optimize carbon gain in fluctuating light? Journal of Experimental Botany, 66(9), 2437-2447. https://doi.org/10.1093/jxb/erv055

Savvides, A., Fanourakis, D., \& van leperen, W. (2012). Co-ordination of hydraulic and stomatal conductances across light qualities in cucumber leaves. Journal of Experimental Botany, 63(3), 1135-1143. https://doi. org/10.1093/jxb/err348

Schneider, T., Bolger, A., Zeier, J., Preiskowski, S., Benes, V., Trenkamp, S., ... Matsubara, S. (2019). Fluctuating light interacts with time of day and leaf development stage to reprogram gene expression. Plant Physiology, 179(4), 1632-1657. https://doi.org/10.1104/ pp.18.01443

Shahbandeh, M. (2020). Vegetables production worldwide by type 2017. Retrieved from https://www.statista.com/statistics/264065/globalproduction-of-vegetables-by-type/

Sharkey, T. D. (2016). What gas exchange data can tell us about photosynthesis. Plant, Cell \& Environment, 39(6), 1161-1163. https://doi.org/ 10.1111/pce.12641

Sharkey, T. D., Bernacchi, C. J., Farquhar, G. D., \& Singsaas, E. L. (2007). Fitting photosynthetic carbon dioxide response curves for $C(3)$ leaves. Plant, Cell \& Environment, 30(9), 1035-1040. https://doi.org/10.1111/ j.1365-3040.2007.01710.x

Shu, S., Chen, L., Lu, W., Sun, J., Guo, S., Yuan, Y., \& Li, J. (2014). Effects of exogenous spermidine on photosynthetic capacity and expression of 
Calvin cycle genes in salt-stressed cucumber seedlings. Journal of Plant Research, 127(6), 763-773. https://doi.org/10.1007/s10265-0140653-z

Sims, D., \& Pearcy, R. (1993). Sunfleck frequency and duration affects growth rate of the understorey plant, Alocasia macrorrhiza. Functional Ecology, 7(6), 683-689.

Tardieu, F., Parent, B., \& Simonneau, T. (2010). Control of leaf growth by abscisic acid: Hydraulic or non-hydraulic processes? Plant, Cell \& Environment, 33(4), 636-647. https://doi.org/10.1111/j.1365-3040.2009. 02091.x

Tomeo, N. J., \& Rosenthal, D. M. (2018). Photorespiration differs among Arabidopsis thaliana ecotypes and is correlated with photosynthesis. Journal of Experimental Botany, 69(21), 5191-5204. https://doi.org/10. 1093/jxb/ery274

Tounekti, T., Abreu, M. E., Khemira, H., \& Munné-Bosch, S. (2012). Canopy position determines the photoprotective demand and antioxidant protection of leaves in salt-stressed Salvia officinalis L. plants. Environmental and Experimental Botany, 78, 146-156. https://doi.org/10.1016/j. envexpbot.2011.12.037

Vialet-Chabrand, S., Matthews, J. S., Simkin, A. J., Raines, C. A., \& Lawson, T. (2017). Importance of fluctuations in light on plant photosynthetic acclimation. Plant Physiology, 173(4), 2163-2179. https:// doi.org/10.1104/pp.16.01767

Watling, J., Ball, M., \& Woodrow, I. (1997). The utilization of lightflecks for growth in four Australian rain-forest species. Functional Ecology, 11(2), 231-239.

Way, D. A., \& Pearcy, R. W. (2012). Sunflecks in trees and forests: From photosynthetic physiology to global change biology. Tree Physiology, 32(9), 1066-1081. https://doi.org/10.1093/treephys/ tps064

Wu, X., Shu, S., Wang, Y., Yuan, R., \& Guo, S. (2019). Exogenous putrescine alleviates photoinhibition caused by salt stress through cooperation with cyclic electron flow in cucumber. Photosynthesis Research, 141(3), 303-314. https://doi.org/10.1007/ s11120-019-00631-y
Wungrampha, S., Joshi, R., Singla-Pareek, S., \& Pareek, A. (2018). Photosynthesis and salinity: Are these mutually exclusive? Photosynthetica, 56(1), 366-381.

Yang, T., Lv, R., Li, J., Lin, H., \& Xi, D. (2018). Phytochrome A and B negatively regulate salt stress tolerance of Nicotiana tobacum via ABA-Jasmonic acid synergistic cross-talk. Plant and Cell Physiology, 59(11), 2381-2393.

Yang, Y., \& Guo, Y. (2018). Unraveling salt stress signaling in plants. Journal of Integrative Plant Biology, 60(9), 796-804. https://doi.org/10.1111/ jipb.12689

Zhang, Y., Kaiser, E., Zhang, Y., Yang, Q., \& Li, T. (2018). Short-term salt stress strongly affects dynamic photosynthesis, but not steady-state photosynthesis, in tomato (Solanum lycopersicum). Environmental and Experimental Botany, 149, 109-119. https://doi.org/10.1016/j. envexpbot.2018.02.014

Zhang, Y., Kaiser, E., Zhang, Y., Yang, Q., \& Li, T. (2019). Red/blue light ratio strongly affects steady-state photosynthesis, but hardly affects photosynthetic induction in tomato (Solanum lycopersicum). Physiologia Plantarum, 167(2), 144-158.

Zorb, C., Geilfus, C. M., \& Dietz, K. J. (2019). Salinity and crop yield. Plant Biology, 21(Suppl 1), 31-38. https://doi.org/10.1111/plb.12884

\section{SUPPORTING INFORMATION}

Additional supporting information may be found online in the Supporting Information section at the end of this article.

How to cite this article: Zhang Y, Kaiser E, Marcelis LFM, Yang Q, Li T. Salt stress and fluctuating light have separate effects on photosynthetic acclimation, but interactively affect biomass. Plant Cell Environ. 2020;1-15. https://doi.org/10. $1111 /$ pce. 13810 